\title{
The neurobiology of suicide - A Review of post-mortem studies
}

\author{
Karolina Furczyk ${ }^{1 *}$, Barbora Schutová', Tanja M Michel ${ }^{1}$, Johannes Thome ${ }^{1,2}$ and Andreas Büttner ${ }^{3}$
}

\begin{abstract}
The neurobiology of suicidal behaviour, which constitutes one of the most serious problems both in psychiatry and general medical practice, still remains to a large degree unclear. As a result, scientists constantly look for new opportunities of explaining the causes underlying suicidality. In order to elucidate the biological changes occurring in the brains of the suicide victims, studies based on post-mortem brain tissue samples are increasingly being used. These studies employ different research methods to provide an insight into abnormalities in brain functioning on various levels, including gene and protein expression, neuroplasticity and neurotransmission, as well as many other areas. The aim of this paper to summarize the available data on the post-mortem studies, to provide an overview of main research directions and the most up-to-date findings, and to indicate the possibilities of further research in this field.
\end{abstract}

Keywords: Autopsy, Biological Psychiatry, Depression, Genetics, Hypothalamic-pituitary-adrenal (HPA) axis, Neural Plasticity, Neurotransmitter, Proteomics

\section{Introduction}

Suicide is one of the leading causes of death globally for all ages. Every year, nearly one million people die from suicide according to WHO, 2013. It therefore constitutes a serious medical and social problem, and as such calls for profound and systematic research to enable a better understanding of the underlying pathology, as well as the development of new therapeutic approaches. Suicides and suicide attempts are usually associated with mental illness including affective or psychotic disorders as well as alcohol and/or substance abuse disorders [1,2]. Suicide is therefore an important focus of neuropsychiatric research. Among psychiatric disorders, mood disorders, schizophrenia and alcoholism are most often co-morbid with suicide [3]. A number of risk factors for suicidal behaviour has been identified, including stress [4], impulsive-aggressive behaviour [5], chronic disease [6] and hopelessness [7]. On the other hand, protective factors such as a stable relationship, a well-established social network and a dependable financial situation $[8,9]$ have also been described. While many socioeconomic

\footnotetext{
* Correspondence: karolina.furczyk@med.uni-rostock.de

${ }^{1}$ Department of Psychiatry, University of Rostock, Gehlsheimerstrasse 20,

18147, Rostock, Germany

Full list of author information is available at the end of the article
}

correlates for suicide have been identified, the neurobiology of suicide remains less clear. The studies of biological abnormalities associated with suicidal behaviour, performed in biomaterials such as blood cells, cerebrospinal fluid and plasma obtained from suicidal patients, have shed some light on this matter. As a result, an involvement of serotonergic [10-13], dopaminergic and noradrenergic systems $[14,15]$, as well as abnormalities in the hypothalamic-pituitary-adrenocortical axis $[14,16]$ were proposed. However, it is not clear if, and to what extent, those observations reflect the pathomechanisms in the brain. Here, the availability of well-characterized postmortem brain samples of suicide victims has proven very useful for research. This article gives a description of the nature of post-mortem studies, of the opportunities they provide, but also of their limitations. Next, it summarizes the results emerging from these studies and its role in enhancing our understanding of suicide. We have aimed at providing the reader with an overview of primary studies looking at genetics, proteomics, neurotransmitter systems, cell-signaling, neural plasticity and neuroendocrinology, that used specific and reproducible methods [17]. Overall, we aimed at summarizing consistent results, already described and evaluated by a number of different authors. On the other hand, studies showing contradictory results 
reflect the complexity of the presented problems. In order to better point out new research directions, such inconsistent studies have also been included in our review. Last but not least, although we concentrate on the most upto-date findings, we also describe a number of the most important older studies, which have provided the basis for the more recent ones.

\section{Review}

\section{Post-mortem studies in suicide victims}

Post-mortem brain samples obtained from suicide victims and controls offer many new opportunities to study molecular mechanisms underlying suicidal behaviour. In contrast to earlier studies based on peripheral tissues, research enables a direct insight into the neurobiological abnormalities associated with suicide. However, it is important to be aware that those studies need to meet certain criteria [18].

To begin with, a positive opinion of the local ethical commission is mandatory for every study involving the examination of human brain samples. Next, because the brain tissue degrades very easily, the process of collecting samples for post-mortem studies should be carried out with special care. The collection of the samples should ideally take place no longer than 48 hours after death. In order to establish the quality of collected tissue and determine whether it is adequate for measuring protein levels and gene expression, $\mathrm{pH}$ of the samples and the RNA integrity number should be determined. Since methyltransferaseand acetyltransferase-activities measured in brain samples were reported to be relatively preserved and independent of storage duration or post-mortem interval Monoranu et al. [19] proposed to use their levels as stability markers in epigenetic studies. On the other hand, an increased storage period has been shown to influence tryptophan levels, which led to the conclusion that the level of this amino acid might indicate the level of protein degradation in the sample [20]. Next, it is very important to carefully examine the samples for any neuropathological abnormalities. This can be combined with dissecting particular regions of the brain, so that the exact neuroanatomical location of examined molecular processes can be taken into account. Since many psychiatric patients have been on several medications, and a drug addiction is often associated with suicidality, it is also advisable to obtain an accurate toxicological screening of the samples. Alternatively, toxicological tests can be performed using the blood of the subjects. Last but not least, a "psychological autopsy" should be obtained from the subjects' families and friends, including psychiatric diagnoses, physical disorders, childhood history, possibilities of early life trauma and history of adverse life events. Nowadays, post-mortem brain collection programs [21] have minimized the difficulties resulting from these prerequisites, readily offering samples collected using standardized methods. Studies based on brain tissue have been focusing different immunological and biochemical mechanisms, as well as gene expression and brain cytoarchitecture. Below are presented the key topics of this research in relation to suicidality.

\section{Genetic studies}

Looking at a possible role of various genetic factors in suicidal behaviour can broaden our knowledge of different neurobiological elements responsible for this pathology. A number of studies have focused on one or several genes at a time, comparing suicide victims with controls. This led to the identification of genetic predisposing factors, such as WFS1 [22,23] or p75NTR [24] as well as many others. On the other hand, many researchers proposed an involvement of a whole family of genes or certain pathways rather than just single genes in the pathology of different psychiatric disorders [25,26]. For example, Must et al. [27] found common variations in a group of genes located in the $4 p$ locus to be related to completed suicide in male individuals. However, to confirm the biological relevance of these studies, it is necessary to replicate the findings in similar and comparable clinical samples with comprehensive coverage of the variants at a particular candidate locus [28]. To this end, genome-wide association studies and mRNA expression studies can help to verify to the significance of previous reports and distinguish biochemical pathways and processes particularly important to the pathophysiology of suicide. The association studies provide a powerful tool for discovering the strongest and most common links between different genes and suicide. The expression studies enable a detailed description of gene expression patterns characteristic for different brain regions. In order to obtain reliable results, it is crucial to match the groups of studied subjects and controls according to age, sex, ethnic background and post-mortem intervals. A promising approach for gene expression studies is the use of oligonucleotide microarrays for the analysis of mRNA levels in the brain tissue. In order to ensure high dependability of the final results, several microarray RNA integrity indicators can be used, such as noise (RawQ) or consistent $\beta$-actin and glyceraldehyde-3-phosphate dehydrogenase (GAPDH) $5^{\prime} / 3^{\prime}$ signal ratios. However, there is some controversy in relation to the idea of the housekeeping genes and, since the levels of the mRNA for $\beta$-actin and GAPDH have also been found to be dependent of cellular profiles and activation, there is a need for finding new methods of controlling the RNA integrity [29]. When analyzing the whole genome, the researchers inevitably face the problem of processing large amounts of complex information. It is therefore important to use reliable tools to summarize and functionally explore the collected data. Here, electronic data bases, as well as gene ontology and enrichment 
algorithms prove indispensable. Another important element is the implementation of sufficiently stringent significance criteria to identify differentially expressed genes biologically relevant to suicide. One of the commonly used tests is the combination of an ANOVA and subsequent t-tests, also referred to as Fisher protected least significant difference (LSD) test [28]. What is more, when running multiple tests it is always important to confirm the statistical significance using corresponding tools, for example the Bonferroni correction [30]. The analysis of gene ontology categories is one of the possibilities to organize the collected data and transparently present the role of the distinguished genes. Sequeira et al. [28] looked at patterns of gene expression in the limbic system of suicide victims to identify differentially expressed genes. The vast majority of expression changes were observed in the amygdala and hippocampus. Amongst the most strongly overrepresented genes where those involved in transcriptional regulation and metabolism: APLP2, BACE1, SYT4, ADCY8, GABRA1 and GABRB1. The identification of the adenylate cyclase 8 gene (ADCY8) confirms previous evidence of a possible involvement of the adenyl cyclase (AC) signaling system in the pathophysiology of suicide (see below). Interestingly, the findings are paralleled by the reports from animal studies: APLP2 knockout mice present with a reduction in both density and number of docked vesicles at the active zone [31], while SYT4 knockouts display reduced levels of anxiety and depression-like behaviour [32]. Sequeira and colleagues also approach a problem of a possible confounding effect on the gene expression by psychoactive drugs.

Genetic studies offer a unique possibility of comparing the effects of both long-term substance abuse (in subjects with documented chronic dependence) and acute substance exposure (in subjects without such history but with positive toxicological screening) on gene expression. The same research group performed gene expression analyses in 17 cortical and subcortical brain regions from suicide victims with and without major depression and controls [33]. They observed the highest number of suicide specific alterations in prefrontal cortical areas and hippocampus (HIP). With the use of the gene ontology analysis, alterations of synaptic neurotransmission and intracellular signaling were revealed. Among these, glutamatergic [34] and GABAergic related genes were globally altered. Thalmeier et al. [35] also performed a classification of the differentially expressed genes according to their biological function and statistical analyses of the data, using post-mortem orbitofrontal cortex of violent suicide victims and control subjects. As a result, they found nine particularly interesting transcripts (CDCA7L, CDH12, EFEMP1, MLC1, PCDHB5, PTPRR, S100A13, SCN2B, and ZFP36). The subsequent pathway analysis showed that the gene ontology categories 'central nervous system development', 'homophilic cell adhesion', 'regulation of cell proliferation' and 'transmission of nerve impulse' were significantly enriched. In a re-analysis of a large set of Affymetrix Human Genome U133A microarray data, Kim et al. [36] compared gene expression levels between suicide completers vs. nonsuicide groups within two diagnostic groups, namely bipolar disorder and schizophrenia. Among bipolar samples, 13 genes and among schizophrenia samples, 70 genes were found to be differentially expressed. According to real-time quantitative PCR data, PLSCR4 and EMX2 were significantly down-regulated in the schizophrenia suicide completers, but not in patients with bipolar disorder. One of the genes found to be upregulated in the bipolar group was gamma-amino butyric acid A receptor, $\alpha 5$ subunit (GABRA5), which, similarly to the finding of GABRA1 up-regulation by Sequeira et al. [28], indicates a possible involvement of the GABAergic neurotransmitter system in suicide. The authors concluded that, since the overlap of genes among the two diagnostic groups was small, a larger number of disorder-specific genes was found. This suggests that disorder-specific pathways dominate over common pathways at the molecular level. Sibille and colleagues [37] used DNA microarrays to conduct a large-scale gene expression analysis in two regions of the human prefrontal cortex obtained from postmortem matched groups of subjects with major depression who died by suicide, and control subjects who died from other causes and were free from psychiatric disorders. Although the authors investigated molecular and cellular pathways potentially involved in depression and suicidal behaviour, and tested several hypotheses of disease pathology and of their putative molecular impact, including changes in single genes, the existence of subgroups of patients or disease subtypes, or the possibility of common biological pathways being affected in the disease process, no evidence for molecular differences that correlated with depression and suicide was found. As a result, the authors hypothesized that either the research methods they used were not sensible enough, or the pathology characteristic for depression was localized in other brain areas and possibly rather associated with post-transcriptional effects and/or changes in protein levels or functions, than with altered transcription in the prefrontal cortex (PFC) Table 1 provides an overview of the genes possibly involved in suicide.

\section{Proteomics}

The analysis of proteome, defined as an entity of all proteins of a cell, a tissue or an organism at a certain time and under exact defined conditions [38] , can help identify new suicide-associated proteins or protein modifications. The proteome is by definition highly dynamic and variable, i.e. easily influenced by a change in various intraand extracellular processes. Similarly, the variety of factors 
Table 1 Genes possibly involved in suicide

\begin{tabular}{|c|c|c|c|c|c|}
\hline $\begin{array}{l}\text { Gene } \\
\text { symbol }\end{array}$ & Description & Change & Location & Diagnosis & Reference \\
\hline $\mathrm{A} 2 \mathrm{M}$ & alpha-2-macroglobulin & upregulation & PFC & $\mathrm{SCH}$ & 35 \\
\hline$A B C G 2$ & $\begin{array}{l}\text { ATP-binding cassette, sub-family G(WHITE), } \\
\text { member } 2\end{array}$ & upregulation & PFC & $\mathrm{aSCH}$ & 35 \\
\hline ADCY8 & adenylate cyclase 8 (brain) & upregulation & LS & MD & 27 \\
\hline ADRA2A & adrenoceptor alpha $2 \mathrm{~A}$ & $\begin{array}{l}\text { higher frequency of the } \\
\text { C1291G SNP }\end{array}$ & G & upregulated & 73,115 \\
\hline ADRA2B & adrenoceptor alpha 2B & $\begin{array}{l}\text { higher frequency of the } \\
\text { rs1018351 SNP }\end{array}$ & G & NC & 116 \\
\hline AGT & $\begin{array}{l}\text { angiotensinogen (serpin peptidase inhibitor, } \\
\text { clade A, member } 8 \text { ) }\end{array}$ & downregulation & PFC & $\mathrm{SCH}$ & 35 \\
\hline AGXT2L1 & alanine-glyoxylate aminotransferase 2-like 1 & downregulation & PFC & $\mathrm{SCH}$ & 35 \\
\hline AHCYL1 & S-adenosylhomocysteine hydrolase-like 1 & downregulation & PFC & $\mathrm{SCH}$ & 35 \\
\hline ALDH1L1 & aldehyde dehydrogenase 1 family, member L1 & downregulation & PFC & $\mathrm{SCH}$ & 35 \\
\hline APLP2 & amyloid beta (A4) precursor-like protein 2 & upregulation & $\mathrm{L}$ & MD & 27 \\
\hline APOE & Apolipoprotein E & downregulation & PFC & $\mathrm{SCH}$ & 35 \\
\hline APOLD1 & apolipoprotein $L$ domain containing 1 & downregulation & PFC & $\mathrm{SCH}$ & 35 \\
\hline ATP1A2 & ATPase, $\mathrm{Na}+/ \mathrm{K}+$ transporting, alpha $2(+)$ polypeptide & downregulation & PFC & $\mathrm{SCH}$ & 35 \\
\hline ATP1B2A & ATPase, $\mathrm{Na}+/ \mathrm{K}+$ transporting, beta 2 polypeptide & downregulation & PFC & $\mathrm{SCH}$ & 35 \\
\hline BACE1 & beta-site APP-cleaving enzyme 1 & upregulation & LS & MD & 27 \\
\hline $\mathrm{BBOX} 1$ & butyrobetaine (gamma), 2-oxoglutarate dioxygenase 1 & downregulation & PFC & $\mathrm{SCH}$ & 35 \\
\hline BDNF & brain-derived neurotrophic factor & downregulatoin & PFC, & HIP NC & 173,174 \\
\hline C3 & complement component 3 & upregulation & PFC & $\mathrm{SCH}$ & 35 \\
\hline CD74 & $\begin{array}{l}\text { CD74 molecule, major histocompatibility complex, } \\
\text { class II invariant chain }\end{array}$ & upregulation & PFC & $\mathrm{SCH}$ & 35 \\
\hline CDCA7L & cell division cycle associated 7-like & not characterised & PFC & NC & 34 \\
\hline $\mathrm{CDH} 12$ & cadherin 12, type 2 (N-cadherin 2) & not characterised & PFC & NC & 34 \\
\hline CHI3L1 & chitinase 3-like 1 (cartilage glycoprotein-39) & downregulation & PFC & $\mathrm{BD}$ & 35 \\
\hline CLDN10 & claudin 10 & downregulation & PFC & $\mathrm{SCH}$ & 35 \\
\hline COMT & catechol-O-methyltransferase & $\begin{array}{l}\text { higher frequency of the } \\
\text { val158met SNP }\end{array}$ & G & $\begin{array}{l}\mathrm{NC} \text {, male } \\
\text { suicides only }\end{array}$ & 125 \\
\hline $\mathrm{CRH}$ & corticotropin releasing hormone & upregulation & PFC & $\mathrm{SCH}$ & 35 \\
\hline CSF1R & colony stimulating factor 1 receptor & upregulation & PFCS & $\mathrm{CH}$ & 35 \\
\hline CX3CR1 & chemokine (C-X3-C motif) receptor 1 & upregulation & PFC & $\mathrm{SCH}$ & 35 \\
\hline DARPP-32 & $\begin{array}{l}\text { protein phosphatase 1, regulatory (inhibitor) } \\
\text { subunit } 1 \mathrm{~B}\end{array}$ & downregulation & PFC & $\mathrm{SCH}$ & 128 \\
\hline DDIT4 & DNA-damage-inducible transcript 4 & downregulation & PFC & $\mathrm{SCH}$ & 35 \\
\hline DUSP6 & dual specificity phosphatase 6 & upregulation & PFC & $\mathrm{SCH}$ & 35 \\
\hline EFEMP1 & EGF-containing fibulin-like extracellular matrix protein 1 & downregulation & PFC & $\mathrm{SCH}$ & 35 \\
\hline EFEMP1 & EGF containing fibulin-like extracellular matrix protein 1 & not characterised & PFC & NC & 34 \\
\hline EIF5A & eukaryotic translation initiation factor $5 \mathrm{~A}$ & downregulation & PFC & $\mathrm{SCH}$ & 35 \\
\hline EMX2 & empty spiracles homolog 2 (Drosophila) & downregulation & PFC & $\mathrm{SCH}$ & 34,35 \\
\hline $\mathrm{EMX} 2$ & empty spiracles homolog 2 (Drosophila) & downregulation & PFC & $\mathrm{BD}$ & 35 \\
\hline EPHX1 & epoxide hydrolase 1, microsomal (xenobiotic) & downregulation & PFC & $\mathrm{SCH}$ & 35 \\
\hline EVC & Ellis van Creveld syndrome & $\begin{array}{l}\text { higher frequency of the } \\
\text { rs1383180 polymorhism }\end{array}$ & G & $\begin{array}{l}\mathrm{NC} \text {, male } \\
\text { suicides only }\end{array}$ & 26 \\
\hline FAM107A & family with sequence similarity 107 , member $\mathrm{A}$ & downregulation & PFC & $\mathrm{SCH}$ & 35 \\
\hline
\end{tabular}


Table 1 Genes possibly involved in suicide (Continued)

\begin{tabular}{|c|c|c|c|c|c|}
\hline FGFR3 & $\begin{array}{l}\text { fibroblast growth factor receptor } 3 \text { (achondroplasia, } \\
\text { thanatophoric dwarfism) }\end{array}$ & downregulation & PFC & $\mathrm{SCH}$ & 35 \\
\hline FXYD1 & $\begin{array}{l}\text { FXYD domain containing ion transport regulator } 1 \\
\text { (phospholemman) }\end{array}$ & downregulation & PFC & $\mathrm{SCH}$ & 35 \\
\hline GABRA1 & gamma-aminobutyric acid (GABA) A receptor, alpha 1 & upregulation & LS & $\mathrm{MD}$ & 27 \\
\hline GABRA5 & gamma-aminobutyric acid (GABA) A receptor, alpha 5 & upregulation & PFC & $\mathrm{BD}$ & 34,35 \\
\hline GABRB1 & gamma-aminobutyric acid (GABA) A receptor, beta 1 & upregulation & LS & $\mathrm{MD}$ & 27 \\
\hline GLUL & glutamate-ammonia ligase (glutamine synthetase) & downregulation & PFC & $\mathrm{SCH}$ & 35 \\
\hline HLA-DPA1 & major histocompatibility complex, class II, DP alpha 1 & upregulation & PFC & $\mathrm{SCH}$ & 35 \\
\hline HLA-DRA & major histocompatibility complex, class II, DR alpha & upregulation & PFC & $\mathrm{SCH}$ & 35 \\
\hline HSPB1 & heat shock 27 kDa protein 1 & downregulation & PFC & $\mathrm{SCH}$ & 35 \\
\hline HTR2C & $\begin{array}{l}\text { 5-hydroxytryptamine (serotonin) receptor } 2 \mathrm{C} \text {, } \\
\mathrm{G} \text { protein-coupled }\end{array}$ & $\begin{array}{l}\text { higher frequency of the } \\
\text { Cys } 23 \text { Ser polymorhism }\end{array}$ & G & $\begin{array}{l}\mathrm{NC} \text {, female } \\
\text { suicides only }\end{array}$ & 84 \\
\hline ID4 & $\begin{array}{l}\text { inhibitor of DNA binding 4, dominant negative } \\
\text { helix-loop-helix protein }\end{array}$ & downregulation & PFC & $\mathrm{SCH}$ & 36 \\
\hline IL17RB & interleukin 17 receptor B & downregulation & PFC & $\mathrm{SCH}$ & 35 \\
\hline ITGB4 & integrin, beta 4 & downregulation & PFC & $\mathrm{SCH}$ & 35 \\
\hline ITPKB & inositol 1,4,5-trisphosphate 3-kinase B & downregulation & PFC & $\mathrm{SCH}$ & 35 \\
\hline LAPTM5 & $\begin{array}{l}\text { lysosomal associated multispanning } \\
\text { membrane protein } 5\end{array}$ & upregulation & PFC & $\mathrm{SCH}$ & 35 \\
\hline LDLR & low density lipoprotein receptor & downregulation & PFC & $\mathrm{BD}$ & 35 \\
\hline LOC645745 & metallothionein $1 \mathrm{H}$-like protein & downregulation & PFC & $\mathrm{SCH}$ & 35 \\
\hline ITrkB & neurotrophic tyrosine kinase, receptor, type 2 & downregulation & PFC, & HIP NC & 171 \\
\hline METTL7A & methyltransferase like $7 \mathrm{~A}$ & downregulation & PFC & $\mathrm{SCH}$ & 35 \\
\hline MLC1 & $\begin{array}{l}\text { megalencephalic leukoencephalopathy with } \\
\text { subcortical cysts } 1\end{array}$ & downregulation & PFC & $\mathrm{SCH}$ & 35 \\
\hline MLC1 & $\begin{array}{l}\text { megalencephalic leukoencephalopathy with } \\
\text { subcortical cysts } 1\end{array}$ & not characterised & PFC & NC & 34 \\
\hline MT1E & metallothionein $1 \mathrm{E}$ (functional) & downregulation & PFC & $\mathrm{SCH}$ & 35 \\
\hline MT1F & metallothionein 1F (functional) & downregulation & PFC & $\mathrm{SCH}$ & 35 \\
\hline MT1G & metallothionein $1 \mathrm{G}$ & dcownregulation & PFC & $\mathrm{SCH}$ & 35 \\
\hline MT1H & metallothionein $1 \mathrm{H}$ & downregulation & PFC & $\mathrm{SCH}$ & 35 \\
\hline MT1M & metallothionein $1 \mathrm{M}$ & downregulation & PFC & $\mathrm{SCH}$ & 35 \\
\hline MT1X & metallothionein $1 \mathrm{X}$ & downregulation & PFC & $\mathrm{SCH}$ & 35 \\
\hline NAV2 & neuron navigator & downregulation & PFC & $\mathrm{BD}$ & 35 \\
\hline NDRG2 & NDRG family member 2 & downregulation & PFC & $\mathrm{SCH}$ & 35 \\
\hline $\mathrm{NOTCH} 2$ & Notch homolog 2 (Drosophila) & downregulation & PFC & $\mathrm{SCH}$ & 35 \\
\hline NPY & neuropeptide $Y$ & upregulation & PFC & $\mathrm{SCH}$ & 35 \\
\hline NTRK2 & neurotrophic tyrosine kinase, receptor, type 2 & downregulation & PFC & $\mathrm{SCH}$ & 35 \\
\hline NTSR2 & neurotensin receptor 2 & downregulation & PFC & $\mathrm{SCH}$ & 35 \\
\hline P2RY13 & purinergic receptor P2Y, Gprotein coupled, 13 & upregulation & PFC & $\mathrm{SCH}$ & 35 \\
\hline p75NTR (NGFR) & nerve growth factor receptor & $\begin{array}{l}\text { higher frequency of the missense } \\
\text { polymorphism (S205L) }\end{array}$ & G & $\mathrm{MD}$ & 23 \\
\hline PCDHB5 & protocadherin beta 5 & NC & PFC & NC & 34 \\
\hline PLSCR4 & phospholipid scramblase 4 & downregulation & PFC & $\mathrm{SCH}$ & 34,35 \\
\hline PLSCR4 & phospholipid scramblase 4 & downregulation & PFC & $\mathrm{BD}$ & 35 \\
\hline PPAP2B & phosphatidic acid phosphatase type $2 B$ & downregulation & PFC & $\mathrm{SCH}$ & 35 \\
\hline PRKCl & protein kinase $C$, iota & upregulated & PFC & NC & 150 \\
\hline
\end{tabular}


Table 1 Genes possibly involved in suicide (Continued)

\begin{tabular}{|c|c|c|c|c|c|}
\hline PTPRR & protein tyrosine phosphatase, receptor type, $R$ & downregulation & PFC & $N C$ & 34 \\
\hline RAB31 & RAB31, member RAS oncogene family & downregulation & PFC & $\mathrm{SCH}$ & 35 \\
\hline RHOBTB34 & Rho-related BTB domain containing 3 & downregulation & PFC & $\mathrm{SCH}$ & 35 \\
\hline S100A13 & S100 calcium binding protein A13 & not characterised & PFC & NC & 34 \\
\hline SAT1 & spermidine/spermine N1-acetyltransferase 1 & $\begin{array}{l}\text { downregulation, higher frequency } \\
\text { of the rs6526342 SNP }\end{array}$ & PFC & $\mathrm{MD}$ & $\begin{array}{l}186,187,188, \\
189,190,192\end{array}$ \\
\hline SCN2B & $\begin{array}{l}\text { sodium channel, voltage-gated, } \\
\text { type II, beta subunit }\end{array}$ & not characterised & PFC & NC & 34 \\
\hline SDC2 & $\begin{array}{l}\text { syndecan } 2 \text { (heparan sulfate proteoglycan 1, } \\
\text { cell surfaceassociated, fibroglycan) }\end{array}$ & downregulation & PFC & $\mathrm{SCH}$ & 35 \\
\hline SDC4 & syndecan 4 (amphiglycan, ryudocan) & downregulation & PFC & $\mathrm{SCH}$ & 35 \\
\hline SLC14A1 & $\begin{array}{l}\text { solute carrier family } 14 \text { (urea transporter), member } 1 \\
\text { (Kidd blood group) }\end{array}$ & downregulation & PFC & $\mathrm{SCH}$ & 35 \\
\hline SLC1A3 & $\begin{array}{l}\text { solute carrier family } 1 \text { (glial high affinity glutamate } \\
\text { transporter), member } 3\end{array}$ & downregulation & PFC & $\mathrm{SCH}$ & 35 \\
\hline SLC25A23 & $\begin{array}{l}\text { solute carrier family } 25 \text { (mitochondrial carrier; } \\
\text { phosphate carrier), member } 23\end{array}$ & upregulation & PFC & $\mathrm{SCH}$ & 35 \\
\hline SLC4A4 & $\begin{array}{l}\text { solute carrier family } 4 \text {, sodium bicarbonate } \\
\text { cotransporter, member } 4\end{array}$ & downregulation & PFC & $\mathrm{SCH}$ & 35 \\
\hline SLC6A3 & $\begin{array}{l}\text { solute carrier family } 6 \text { (neurotransmitter transporter, } \\
\text { dopamine), member } 3\end{array}$ & $\begin{array}{l}\text { higher frequency of the } \\
\text { rs403636 SNP }\end{array}$ & G & NC & 116 \\
\hline SLC7A11 & $\begin{array}{l}\text { solute carrier family 7, (cationic amino acid } \\
\text { transporter, y+system) member } 11\end{array}$ & downregulation & PFC & $\mathrm{SCH}$ & 35 \\
\hline SOX9 SRY & (sex determining region Y)-box 9 & downregulation & PFC & $\mathrm{SCH}$ & 35 \\
\hline SPON1 & spondin 1, extracellular matrix protein & downregulation & PFC & $\mathrm{SCH}$ & 35 \\
\hline STCH & $\begin{array}{l}\text { stress } 70 \text { protein chaperone, } \\
\text { microsome-associated, } 60 \mathrm{kDa}\end{array}$ & upregulation & PFC & $\mathrm{BD}$ & 35 \\
\hline SYT4 & $\begin{array}{l}\text { synaptotagmin IV upregulation LS MD } 27 \text { TIMP1 } \\
\text { TIMP metallopeptidase inhibitor } 1\end{array}$ & downregulation & PFC & $\mathrm{BD}$ & 35 \\
\hline TM4SF1 & transmembrane $4 \mathrm{~L}$ six family member 1 & downregulation & PFC & $\mathrm{BD}$ & 35 \\
\hline TNFSF10 & tumor necrosis factor (ligand) superfamily, member 10 & upregulation & PFC & $\mathrm{SCH}$ & 35 \\
\hline TP53BP2 & tumor protein p53 binding protein, 2 & downregulation & PFC & $\mathrm{SCH}$ & 35 \\
\hline TPD52L1 & tumor protein D52-like 1 & downregulation & PFC & $\mathrm{SCH}$ & 35 \\
\hline $\mathrm{TPH} 2$ & tryptophan hydroxylase 2 & $\begin{array}{l}\text { higher frequeny of the } \\
\text { rs1386494 SNP }\end{array}$ & G & NC & 88 \\
\hline TRIM23 & tripartite motif-containing 23 & upregulation & PFC & $\mathrm{BD}$ & 35 \\
\hline TUBB2B & tubulin, beta $2 \mathrm{~B}$ & downregulation & PFC & $\mathrm{SCH}$ & 35 \\
\hline TYROBP & TYRO protein tyrosine kinase binding protein & upregulation & PFC & $\mathrm{SCH}$ & 35 \\
\hline VIL2 & villin 2 (ezrin) & downregulation & PFCS & $\mathrm{CH}$ & 35 \\
\hline WFS1 & Wolfram syndrome 1 (wolframin) & $\begin{array}{l}\text { higher frequency of the } \\
611 R / 611 \text { genotype }\end{array}$ & G & $N C$ & 21,22 \\
\hline ZFP36 & ZFP36 ring finger protein & not characterised & PFC & NC & 34 \\
\hline $\mathrm{ZHX} 2$ & zinc fingers and homeoboxes 2 & downregulation & PFC & $\mathrm{BD}$ & 35 \\
\hline $\mathrm{ZIC1}$ & $\begin{array}{l}\text { Zic family member } 1 \\
\text { (odd-paired homolog, Drosophila) }\end{array}$ & downregulation & PFC & $\mathrm{BD}$ & 35 \\
\hline
\end{tabular}

implicated in the pathophysiology of suicide might predominantly affect the proteome rather than the more stable genome. It is important to remember that, since every single gene determines a multitude of gene products, in order to understand molecular processes in neuropsychiatric disorders, it is necessary to unravel signal transduction pathways and complex interaction networks which affect proteins, not only DNA and mRNA. Proteomics utilizes high-throughput mass spectrometric methods for protein identification that can help to reveal protein expression 
levels, posttranslational modifications and protein-protein interactions [39]. On the other hand, the use of proteomics to examine the modifications in protein expression also enables the identification of the new candidate genes for suicide. Thanks to an international initiative, the Human Proteome Organization (HUPO) was founded. HUPO is an international scientific organization representing and promoting proteomics through international cooperation and collaborations. Through ensuring public availability of collected data, HUPO supports the development of proteomics and fosters further research (www.HUPO.org). The field of proteomic studies of post-mortem brain tissue is still relatively unexplored. Schlicht et al. [40] used proteomic analysis by means of two-dimensional polyacrylamide gel electrophoresis (2D-PAGE) to compare protein patterns in the post-mortem PFC tissues of suicide victims and controls. They found three proteins, which were present exclusively in the suicide group. By means of mass spectrometry, they managed to identify these proteins as a phosphorylated isoform of glial fibrillary acidic protein (GFAP), manganese superoxidase dismutase (SOD2) and $\alpha$ crystallin chain B (CRYAB). GFAP is a component of glial filaments specific to astrocytes and was found upregulated in reactive gliosis, as well as in several neurodegenerative disorders [41]. Interestingly, it is exactly the phosphorylated form of GFAP that has been implicated in the pathophysiology of psychiatric disorders [42]. SOD2 is a major antioxidant enzyme involved in the detoxification of superoxide radicals. Schlicht and colleagues propose to interpret their finding of SOD2 in the PFC of suicide subjects as a compensatory mechanism under the conditions of intensified oxidative stress. This corresponds well with the reports of elevated levels of this enzyme in different psychiatric disorders [34,43-45]. On the other hand, a study by Pae et al. [46] failed to support an association of manganese superoxide dismutase (one of the antioxidant enzyme) gene polymorphism (MnSOD: Ala-9Val) with the development of mood disorders or their clinical parameters in the Korean population. Nevertheless, looking at the association between the oxidative stress and suicidality seems to be a new interesting direction of research.

The third protein Schlicht and colleagues found present only in suicidal victims, CRYAB, belongs to the low molecular heat shock proteins (small heat shock protein, $\mathrm{sHsp})$. One of its important roles is the protection of intermediate filaments, such as GFAP in astrocytes, against aggregation and inactivation. The authors conclude that the expression of these three proteins in the PFC of suicide victims might indicate a possible existence of an intermitting component between glial function and suicidal behaviour. They suggest that the serotonergic system can indeed play such a role, especially because animal studies showed 5HTsensitive astrocytes from 5-HT-depleted regions of rat brain revealed up-regulation of GFAP synthesis [47]. This hypothesis is consistent with many reports confirming an involvement of the serotonergic system in suicide (see below). Brunner et al. [48] performed proteomic analyses of the CSF in un-medicated patients with major depressive disorder with and without a history of suicide attempt. Two-dimensional gel electrophoresis revealed that suicide attempters differed from non-attempters in one protein with an approximate molecular weight of $33 \mathrm{kD}$ and an isoelectric point of 5.2. The authors concluded that proteomic analysis of the CSF could be a promising non hypothesis-driven screening method for the detection of new candidate genes in neurobiological suicide research.

\section{Neurotransmitter systems Serotonergic system}

A vast amount of data documents a role of abnormalities in the serotonergic system in suicidal behaviour. Different elements of this complex system, including serotonin receptors, serotonin transporter and tryptophan hydroxylase, the rate-limiting enzyme in the synthesis of serotonin, have been researched in this respect. Quite understandably, numerous post-mortem studies have also focused on changes in the serotonergic system.

\section{Serotonin receptors}

Out of the 14 known different receptors for serotonin, the post-mortem studies have mainly focused on $5 \mathrm{HT}-1 \mathrm{~A}$, 5HT-1B, 5HT-1D, 5HT-2A, 5HT-2C, which have been proposed to play a role in depressive disorder, increased stress response, anxiety and suicidal behaviour. 5HT-1A serotonin receptors have been studied using autoradiographic methods and homogenate binding methods with 8-hydroxy-2-(di-n-propyloamino) tetralin (8-OH-DPAT) as the ligand. Stockmeier and colleagues [49] reported that the binding of $[3 \mathrm{H}] 8-\mathrm{OH}-\mathrm{DPAT}$ to serotonin-1A receptors was significantly increased in the midbrain dorsal raphe of suicide victims with major depression, as compared with control subjects. The density of 5HT-1A receptor binding sites in the PFC was also found increased in nonviolent suicide victims [50]. This result however conflicts with a number of other studies focused on the same receptors in the PFC, which showed no changes in this region [51-53]. However, a more recent study by Stockmeier et al. [54] has shown that, while there was no difference in the agonist-binding to $5 \mathrm{HT}-1 \mathrm{~A}$ receptors between depressed patients and control subjects, the antagonistbinding was significantly decreased in outer layers of the PFC obtained from subjects diagnosed with major depressive disorder, the psychiatric diagnosis most common in suicide victims. Furthermore, Arango et al. [55] described differences in density of [3H]8-OH-DPAT binding between nonviolent suicide victims and control subjects in Brodmann areas 8 and 9. Interestingly, this different density was observed in male suicide victims only. Finally, an 
increase in 5HT-1A receptor binding sites in the CA1 area of the HIP of suicide victims compared to controls was described by Joyce and colleagues [56]. However, other studies reported no differences in hippocampal 5HT-1A receptor binding [52,53]. Arraz et al. [51] observed a significant decrease in the 5HT-1A binding affinity in suicide victims who died as a result of an overdose of tricyclic antidepressants. They tried to explain this by the higher sensitivity of this binding site to the acute administration of TCA.

In summary, although the results of studies focusing on a role of 5HT1A receptors in suicidality are inconsistent, it appears that there may be an increase in their density in particular areas of the brain (raphe nuclei, Brodmann area 8 and 9). The serotonin $1 \mathrm{~B}$ receptor has been suggested to play a role in suicide, aggression and substance abuse [57]. New et al. [58] reported an association between the G861C polymorphism in the coding region of the $5 \mathrm{HT}-1 \mathrm{~B}$ receptor gene and susceptibility to suicide attempts in Caucasian subjects, while, concordant to the results of other studies based on mixed population $[59,60]$, no association was observed in the ethnically mixed overall sample. Another study [61], including two ethnically homogenous samples of German and Slavic origin, does not support the involvement of this 5HT-1B receptor polymorphism in suicide. In the above mentioned study Arraz et al. [51] looked also at the 5HT-1D serotonin receptor. A significant decrease in 5HT-1D binding affinity was found in depressed suicide victims, while the number of 5HT-1D binding sites showed a significant decrease in the non-depressed suicide victims. 5HT-2A, another serotonin receptor with a possible role in suicidality, can be labeled by several ligands, such as ketaserin, spiperon or lysergic acid diethyl amide (LSD), none of them completely specific. The use of nonspecific ligands can explain inconsistent results of studies focusing on this receptor. While the results of the first study by Stanley and Mann [62], showing increased 5HT-2A binding sites in frontal cortex (FC) of suicide victims, were later confirmed by further research [63-68], a number of other studies presented contradictory results with no difference [51,53,69-72] or, in one case, a decrease [73] in this receptor binding. In order to eliminate these discrepancies, Pandey et al. [66] examined both protein and mRNA expression of 5HT-2A receptors in several regions of the post-mortem brains of teenage suicide victims. They found that both protein and mRTA expression levels of these receptors were significantly increased in the PFC and the HIP, but not in the nucleus accumbens of suicide victims. These results were next confirmed by Escriba et al. [74]. Shelton et al. [75] reported 5HT-2A receptor protein expression in Brodmann area 10 obtained from major depressive disorder subjects, both suicide victims and not, to be increased in comparison to non-depressive subjects. Regarding the $5 \mathrm{HT}-2 \mathrm{C}$ receptor, a regulatory role in mood, appetite and sexual behaviour was suggested [76,77]. Pandey et al. [78] determined the protein and mRNA expression of $5 \mathrm{HT}-2 \mathrm{C}$ receptors in the PFC Brodmann area 9, the HIP and choroid plexus of suicide victims and normal controls. They found higher protein expression in the PFC, but not in other brain regions of suicidal subjects. On the other hand, there was no significant difference in the mRNA expression in any of the studied regions. Since 5HT-2C receptor mRNA undergoes post-translational editing into two different receptor isoforms [79], a possible involvement of this process in the pathophysiology of suicidal behaviour was also suggested. Gurevich et al. [80] found that the pre-mRNA editing of the 5HT-2C receptors at the $C^{\prime}$ site was significantly increased, while the editing at the $\mathrm{D}$ site was decreased, and the $\mathrm{C}$ site showed a trend towards increased editing in the suicide victims with a history of major depression as compared with control subjects. Dracheva et al. [81] described the premRNA editing of the 5HT-2C receptor in subjects with bipolar disorder or schizophrenia. Those of the subjects who died by suicide showed differences in editing localized in dorsolateral PFC, which were not present in subjects who died of natural causes. It has been proposed that 5HT2C-receptor-coupled signaling is altered in suicide victims due to modified $\mathrm{G}$ protein-coupling as a result of mRNA editing [82]. A suggested association between suicide and the single nucleotide polymorphism in the coding region of the 5HT-2C receptor gene, resulting in (Cys22Ser) substitution, although most probably causing functional differences between the two variants [83], has not been proved [84]. However, a significant association was observed between female suicide victims of Slovenian origin and the $\mathrm{SN}$ polymorphism $68 \mathrm{G}>\mathrm{C}$ (Cys23Ser) in 5HT-2C receptor gene [85].

\section{Tryptophan hydroxylase}

Tryptophan hydroxylase is the rate limiting enzyme in the synthesis of serotonin. Post-mortem studies, indicated a greater density and number of TPH-immunoreactive (TPH-IR) neurons in the dorsal raphe nucleus [86] and higher TPH-IR in the dorsal, but not in the median raphe nucleus, in depressed suicide victims [87]. About ten years ago, two isoforms of TPH have been identified, TPH1 and $\mathrm{TPH} 2$, of which the latter is expressed primarily in the brain [88]. The isoforms are encoded by two genes located on different chromosomes. Haplotype and association studies of different SNPs suggest the involvement of the TPH2 gene in suicide. Zill et al. [89] reported a statistically significant association between the rs1386494 SNP of the TPH2 gene and suicide. They also found three TPH2 haplotypes which significantly differed in their distribution between suicide completers and control subjects. In the TPH1 gene in turn, there are two common polymorphisms on intron 7: $\mathrm{A} 218 \mathrm{C}$ and $\mathrm{A} 779 \mathrm{C}$ 
(originally classified as $\mathrm{U}$ and $\mathrm{L}$ for upper and lower band), which are in very high linkage disequilibrium. In one post-mortem study, the AA genotype was associated with higher TPH immunoreactivity and lower 5-HT2A binding in the PFC compared to other genotypes in both suicides and non-suicides, suggesting a regulatory role of this enzyme in the functioning of serotonergic system [90].

\section{Serotonin transporter}

The serotonin transporter, a target protein for a number of antidepressant drugs, including SSRIs, has also been a subject of post-mortem brain studies. Depressed suicides were shown to present with fewer serotonin transporters in the PFC (suicide or major depression), hypothalamus (suicide), occipital cortex (major depression) and brainstem (suicide and major depression) [90,91]. Importantly, this PFC deficit in suicide victims appears localized to the ventromedial PFC (a brain region involved in willed action and decision-making), whereas major depression is associated with lower binding throughout the PFC [92]. On the other hand, Bligh-Glover et al. [93] showed a significant increase in $[(3) \mathrm{H}]$ paroxetine binding to serotonin transporters in the entire dorsal raphe nucleus, progressing from rostral-to-caudal levels in both normal control subjects and suicide victims with major depression. At comparable rostral-to-caudal levels, there were no significant differences in serotonin transporters found between depressed suicide victims and normal control subjects in either the entire dorsal raphe nucleus or its constituent subnuclei. One of the proposed causes of lower serotonin transporter binding in depression and suicide was the prevalence of a short variant ( $\mathrm{S}$ allele) of functional promotor polymorphism of the transporter gene (5-HTTLPR). This theory however has not been confirmed by either post-mortem [92] or imaging studies [94,95]. Zupanc et al. [96] reported no association between polymorphisms in serotonin transporter gene (5-HTT) (polymorphism LPR in promoter and VNTR in the second intron), as well as in different serotonin receptor genes (HTR): HTR1A (polymorphism -1019C >G), HTR1B (polymorphisms $861 \mathrm{G}>\mathrm{C}$ and $-161 \mathrm{~A}>\mathrm{T}$ ), HTR1F (polymorphism $-78 \mathrm{C}>\mathrm{T}$ ) and HTR2A (polymorphism $-1420 \mathrm{C}>\mathrm{T}$ ), and completed alcohol-related suicide.

\section{Noradrenergic and dopaminergic system Adrenergic receptors}

Gross-Isseroff [73] and colleagues reported significantly lower binding to alpha 1-receptors in several brain regions of the suicide group as compared with matched controls. The decrease in receptor density was observed in portions of the PFC, in the temporal cortex (TC) and the caudate nucleus $(\mathrm{CN})$. An increase in alpha 1-adrenergic binding in PFC was confirmed by Arango et al. [97]. Meana and Garcia-Sevilla [98], as well as González et al. [99] showed an increase in the number of alpha 2-adrenoreceptor agonist binding sites in the HIP and the FC of depressed suicide victims. Ordway et al. [100] and Ordway [101] described the same effect in locus coeruleus (LC), the principal source of brain norepinephrine. In contrast to those studies, Gross-Isseroff et al. [102] reported no significant, region-dependent alterations in the density of alpha 2adrenergic receptors in brains of suicide victims as compared to matched controls. Since a few subtypes of adrenergic receptors were described and specifically localised in different parts of the brain (alpha1A, alpha1B and alpha1D as well as alpha2A, alpha2B and alpha2C) $[103,104]$, post-mortem studies provided a possibility to establish differences in receptor subtype locations, in their density and functioning, as well as in their role in sucidality. According to the study by De Paermentier et al. [105], who looked at adrenergic receptors in suicide victims in relation to treatment with antidepressants, the number of alpha1A- and alpha1D-adrenoceptors did not differ significantly between antidepressant-free or antidepressant-treated suicide subjects and controls. In antidepressant-free suicide subjects, the number of alpha2adrenoceptors, however not alpha2A-adrenoceptors in particular, was significantly higher in the TC. In antidepressant-treated suicides, significantly lower numbers of alpha2-adrenoceptors were found in occipital cortex (OC) and HIP (and for alpha2A-adrenoceptors in the $\mathrm{CN}$ and the amygdala) compared to controls. On the other hand, Meana et al. [106] found both the density and affinity of alpha 2A-adrenoceptors in the high-affinity state to be increased, especially in the FC and the hypothalamus (HTH) of depressed suicides, a finding later confirmed by Callado and colleagues [107], who described a greater proportion of alpha2A-adrenoceptors in the highaffinity conformation in the FC of depressed suicide victims. Moreover, González-Maeso et al. [108] described an increase in alpha 2A-adrenoceptor sensitivity in the FC of depressed suicide victims. García-Sevilla et al. [109] reported an up-regulation of alpha 2A-adrenoceptors in the PFC (Brodmann area 9) of suicide subjects. One study reported an increase in biding to beta-adrenergic receptors in the PFC and the TC of the suicide victims [110]. Gurguis et al. [111] examined agonist affinity and coupling efficiency of beta-adrenergic receptors to Gs protein in the brains of ten suicide victims. They found no differences in the receptor densities in either the FC or HIP of suicide victims compared to controls, however, the preliminary results indicated beta-adrenergic receptors supercoupling in suicide victims in both brain regions. Following these findings, Little et al. [112] tested the hypothesis that the pineal beta-adrenergic binding is increased in depressed persons committing suicide, reflecting diminished noradrenergic input. They found no differences in pineal beta-adrenergic receptors between 
suicide subjects with major depression compared to the matched controls.

When comparing the density of beta-adrenoceptors with that of alpha2-adrenoceptors, Sastre et al. [113] found that, in brains of suicide victims, the ratio between alpha2- and beta-adrenoceptors (alpha2-full agonist sites/beta-sites) was greater compared to controls. A genetic study of alpha2Aadrenoceptors revealed - in concordance to the results of most autoradiographic and immunolabelling studies - an increased mRNA expression of the receptor gene in suicide subjects [74]. Sequeira et al. [114] looked at genetic variations of the alpha $2 \mathrm{~A}$-adrenergic receptor gene (ADRA2A) at four loci, including three in the promoter region (g-1800t, c-1291 g and the g-261a), and a potentially functional locus, N251K, which leads to an amino acid change (asparagine to lysine). They found no significant differences at the promoter loci in terms of allelic or genotypic distribution between suicide victims and controls. However, analysis of the functional polymorphism N251K revealed that the $251 \mathrm{~K}$ allele was only present among suicides, though only in three out of 110 cases. These results were not replicated either by MartínGuerrero et al. [115] or by Fukutake et al. [116], although the latter study reported a significant association of the C-1291G SNP in the promoter region of the alpha 2Aadrenergic receptor gene with suicide in Japanese females. A link between the rs1018351 SNP in alpha 2B-adrenergic receptor gene and suicidal attempt was also reported [117]. Since different studies mentioned above confirm alterations in cortical beta- and alpha-adrenergic receptor binding, Arango et al. [118] studied specifically the pigmented neurons of the LC [119], which provide the noradrenergic innervations to the cerebral cortex. In the samples from the suicide group, they observed 23\% fewer LC neurons and a $38 \%$ lower density of LC neurons when compared to control samples. This led them to a conclusion that altered brain noradrenergic neurotransmission in suicide victims may be due to fewer noradrenergic neurons in the $\mathrm{LC}$.

\section{Tyrosine hydroxylase, Catechol-O-methyltransferase}

Tyrosine hydroxylase (TH) is the rate-limiting enzyme for catecholamine synthesis. Ordway and collegaues [100] found concentration levels of TH in LC to be elevated in the samples from suicide victims. Persson et al. [120] studied $\mathrm{TH}$ gene expression and observed a non-significant tendency towards a lower incidence of the TH-KI allele among suicide subjects compared to controls, although there was a significant association of the K3 allele in the subgroup of patients with adjustment disorder and suicide attempt. In other studies a trend for association [121] or no association [122] were reported. Biegon and Fieldust [123] found no difference between suicide victims and controls in the levels of the dopamine beta-hydroxylase (DBH, the last enzyme in the synthesis of neuroepinephrine) immunoreactivity or in the number of TH immunoreactive cells. Catechol-O-methyltransferase is an enzyme metabolizing noradrenaline in the synaptic cleft. COMT has been shown to affect cognition and personality traits as well as neuronal activation [124,125], which suggest it can also play a role in the susceptibility to suicidal behaviour. The COMT gene has a common functional polymorphism, val158met. One post-mortem study found the Val allele less prevalent, and the heterozygote $\mathrm{Val} /$ Met more common in male suicide victims than in controls [126].

\section{Dopaminergic system}

Although there is not much data on the role of the dopaminergic system in suicidality, a reduction in the dopamine turnover (significantly lower concentration of dihydroxyphenylacetic acid) was observed in the $\mathrm{CN}$, putamen (P) and nucleus accumbens (NA) in a post-mortem study of depressed suicide victims [127]. Allard and Norlén [128] reported no difference in Bmax and Kd of the $[3 \mathrm{H}]$ WIN 35,428 ligand binding to dopamine uptake sites in the $\mathrm{CN}$ between the suicide group and controls. Since dopamine-and-cAMP-regulated neuronal phosphoprotein (32 kDa) (DARPP-32) is expressed in brain regions receiving dopaminergic projections, including the PFC, and is implicated in the pathophysiology of schizophrenia, Feldcamp et al. [129] determined the DARPP-32 gene expression in suicide victims with schizophrenia. They found a significant difference in gene expression levels between schizophrenia patients who died by suicide vs. other causes of death, as well as the between the schizophrenia group and controls.

\section{Glutamatergic system}

Based on a known adaptation of the NMDA receptor complex in the rodent cortex in response to chronic antidepressant treatment, Nowak et al. [130] hypothesized glutamatergic dysfunction could be involved in psychopathology underlying suicide. Consequently, they conducted an analysis of the glutamatergic receptors in post-mortem brain probes. They reported a reduced proportion of high affinity, glycine displaceable [3H]CGP39653 binding to glutamate receptors in suicide victims in comparison to age- and post-mortem interval-matched controls. In contrast, neither the potency nor the maximum efficacy of glycine to inhibit [3H]CGP-39653 binding was altered in the $\mathrm{FC}$ of suicide victims compared to controls. The potency of glycine to inhibit $[3 \mathrm{H}] 5,7-$ dichlorokynurenic acid binding to the strychnineinsensitive glycine receptor or the specific binding of [3H]5,7-dichlorokynurenic acid did not differ between the two groups. Likewise, neither basal nor glycine- or glutamate enhanced non-equilibrium binding of $[3 \mathrm{H}]$ 
dizocilpine was altered in suicide victims. Nevertheless, the findings confirm an involvement of the glutamatergic system in suicidality. To further support this, Nowak et al. [119] reported a statistically significant decrease in the potency of zinc to inhibit [(3)H]MK-801 binding to NMDA receptors in the hippocampal but not cortical tissue of suicide subjects. The authors proposed that the alteration in zinc interaction with NMDA receptors may be involved in the psychopathology underlying suicide attempts. However, other studies found no [131] or very little [132] evidence for a role of NMDA-binding sites in the pathophysiology of suicide. Freed and collegues [133] measured the non-NMDA excitatory amino acid receptors by means of analyzing the $[3 \mathrm{H}]$ AMPA binding in the $\mathrm{FC}$, the $\mathrm{CN}$, and the NA of post-mortem human brain tissue samples. They found a pronounced increase in total AMPA binding in the $\mathrm{CN}$ in subjects that had committed suicide when compared to matched controls. An up-regulation of the binding of the AMPA receptor, was also reported in a group of suicide victims by Noga et al. [134]. Different factors interacting with the glutamatergic system should also be taken into account in suicide research. One interesting example is a study by Kalkman [135]. Based on the fact that the glycogen synthase kinase 3 (GSK3) inhibitor, lithium, which has a proven effect against suicide, increased the activity of glutamine synthetase in an animal experiment [136], he proposed that suicide might be prevented by centrally acting GSK3 inhibitors.

\section{Other neurotransmitter systems}

Cheetham et al. [137] studied GABA receptors by quantitating benzodiazepine (BZ) binding sites. They reported the number of $\mathrm{BZ}$ binding sites was significantly greater in the FC of the total group of depressed suicide subjects compared to controls, but did not differ in the TC. Vinod and collegues [138], who looked at the brain samples of subjects with a history of alcohol abuse, found the cannabinoid $\mathrm{CB}(1)$ receptor density in the dorsolateral PFC was higher in patient with alcohol addiction who committed suicide then in those who died of other causes. Western blot analysis confirmed a greater immunoreactivity of the $\mathrm{CB}(1)$ receptor in alcohol dependent suicide victims. The $\mathrm{CB}(1)$ receptor-mediated [(35)S]GTP gamma $\mathrm{S}$ binding also indicated a greater signaling in this group. The same group reported an upregulation of CB1 receptors and agoniststimulated [35S]GTPgammaS binding in the PFC of depressed suicide victims [139].

Table 2 summarizes the findings regarding neurotransmitter systems and suicidality.

\section{Cell-signalling research \\ Protein kinases $A$ and $C$}

A disturbance in a signal-transduction process from cell surface receptors to the nucleus was postulated as a one of the mechanisms underlying suicidal behaviour. As a result, a possible role of protein kinase A, an enzyme involved in the adenyl cyclase (AC) signalling pathway, as well as protein kinase $\mathrm{C}$, a component of the phosphoinositide (PI) signalling system, were investigated. Protein kinase A (PKA), activated by cyclic AMP, works by phosphorylisation of several intracellular proteins and activates certain transcription factors. Two different PKA izoenzymes were identified, known as PKAI and PKAII, both compromised of $\mathrm{R}$ and $\mathrm{C}$ units. The I and II PKA isoenzymes are built of different $\mathrm{R}$ subunits (called RI and RII), each of them consisting of RI $\alpha$ and RI $\beta$ or RII $\alpha$ and RII $\beta$ subunits respectively. Furthermore, three $\mathrm{C}$ subunits, known as $C \alpha, C \beta$ and $C \gamma$, were described. Post-mortem studies showed $3[\mathrm{H}]$-cAMP binding and PKA activity to be significantly decreased in the PFC of suicide victims $[140,141]$. Moreover, a decrease in the catalytic activity of PKA in Brodmann area 9 and the HIP was also observed in suicide subjects [142]. In concordance with this observation, Dwivedi and colleagues [141] reported the protein and mRNA expression of PKA subunits RII $\beta$ and $C \beta$ to be decreased in PFC of suicide subjects when compared with controls. Pandey et al. [143], who looked at the activity of the PKA subunits in the post-mortem brain of teenage suicide victims, found a decreased cAMP binding and PKA activity in the PFC, but not in the HIP. Shelton and colleagues [75] studied 5-HT (2A) receptor abundance and PKA activity in post-mortem brain tissue specimens from persons with a history of major depression. They reported an increased 5-HT(2A) receptor abundance and decreased PKA activity in the depressed sample. 5$\mathrm{HT}(2 \mathrm{~A})$ receptor availability was significantly inversely correlated with PKC activity in controls, but not with PKA activity in the depressed sample. The authors propose these abnormalities of 5-HT(2A) receptor abundance may depend on receptor uncoupling and heterologous regulation by PKA. A study of serotonin 5-HT2A and 5-HT4 binding parameters and their second messengers 1,4,5-inositol triphosphate (IP3) and cyclic adenosyl monophosphate [129] in the FC, HIP, CA and amygdala of suicide victims by Rosel et al. [72] revealed significantly higher number of 5-HT4 receptors and higher second messenger cAMP concentrations in the $\mathrm{FC}$ and $\mathrm{CN}$ of the depressed suicide victims as compared with the control group. Furthermore, significantly increased 5-HT2A binding sites and IP3 concentrations were noted in the $\mathrm{CN}$ of the suicide group, together with a significantly reduced number of 5- HT2A binding sites, higher binding affinity and increased IP3 concentrations in the HIP. Dwivedi et al. [144] studied Rap-1, one of the major substrates of protein kinase A, involved in neuroprotection and synaptic plasticity, which can be directly activated by cAMP through exchange proteins (Epac1, Epac2). They found that Rap-1 activation was significantly reduced in the PFC 
Table 2 Neurotransmitter systems and suicide

\begin{tabular}{|c|c|c|c|c|}
\hline \multicolumn{3}{|l|}{ System element } & \multirow{2}{*}{$\begin{array}{l}\text { Change } \\
\text { upregulated }\end{array}$} & \multirow{2}{*}{$\begin{array}{l}\text { Location } \\
\text { RN, FC }\end{array}$} \\
\hline SEROTONERGIC & Receptors & $5 \mathrm{HT}-1 \mathrm{~A}$ & & \\
\hline & & $5 \mathrm{HT}-1 \mathrm{D}$ & downregulated & PFC \\
\hline & & $5 \mathrm{HT}-2 \mathrm{~A}$ & downregulated & PFC, HIP, FPC \\
\hline & & $5 \mathrm{HT}-2 \mathrm{C}$ & upregulated & PFC \\
\hline & & $5-\mathrm{HT} 4$ & upregulated & $\mathrm{FC}, \mathrm{HIP}, \mathrm{CN}, \mathrm{AN}$ \\
\hline & Enzymes & $\mathrm{TPH}$ & upregulated & $\mathrm{RN}$ \\
\hline & Transporter & Serotonin transporter & downregulated & PFC, RN \\
\hline \multirow[t]{8}{*}{ NORADRENERGIC } & Receptors & Alpha-1 & downregulated & $\mathrm{PFC}, \mathrm{TC}, \mathrm{CN}$ \\
\hline & & Alpha-2 & upregulated in drug-free subjects & HIP, FC, LC, HTH \\
\hline & & & downregulated in antidepressant- treated subjects & OC, HIP \\
\hline & & Alpha-2A & upregulated in drug-free subjects & EC, HTH, PEE \\
\hline & & & downregulated in antidepressanttreated subjects & $\mathrm{AN}, \mathrm{CN}$ \\
\hline & & Beta & upregulated & PFC, TC \\
\hline & & Alpha-2 'Beta ratio & increased & G \\
\hline & Enzymes & $\mathrm{TH}$ & upregulated & LC \\
\hline DOPAMINERGIC & Dopamine turnover & $\begin{array}{l}\text { Dihydroxy- phenylacetic } \\
\text { acid concentration }\end{array}$ & decreased & CN, P. NA \\
\hline \multirow[t]{3}{*}{ GLUTAMATERGIC } & Receptors & NMDA & downregulated & G \\
\hline & & & Zinc inhibition decreased & HIP \\
\hline & & AMPA & upregulated & $\mathrm{CN}$ \\
\hline GABA-ERGIC & Receptors & GABA & upregulated & FC \\
\hline ENDOCANNABINOID & Receptors & $\mathrm{CB}(1)$ & upregulated & PFC \\
\hline
\end{tabular}

and the HIP of the suicide group. This was associated with significant reductions in Rap-1 messenger RNA and protein levels. In contrast, protein level of only Epac-2, but not Epac-1 was significantly increased in the PFC and the HIP of these subjects. To further support an involvement of the AC signalling system in suicidal behaviour, a response to the beta(1)-adrenoceptors agonist-stimulated $\mathrm{AC}$ activity was found significantly lower in post-mortem brain samples from subjects with major depressive disorder [145].

Protein kinase $\mathrm{C}$ is a regulatory enzyme involved in the modulation of many neuronal and cellular functions, such as neurotransmitter synthesis and release, regulation of receptors and ion channels, neuronal excitability, gene expression, secretion and cell proliferation [146]. The PKC family has been sub-grouped into three classes, namely conventional, novel and atypical izoenzymes, which differ in molecular structure and enzymatic activity [147-149]. Pandley et al. [150] found that the binding of $3[\mathrm{H}]$ phorbol 12,13-dibutyrate by PKC was significantly decreased in both membrane and cytosol fractions obtained from the PFC of teenage suicide victims. Both in the PFC and in the HIP of teenage suicides, the PKC activity was decreased, so was the protein expression of conventional isoenzymes. The decreased activity was reflected by significantly decreased mRNA levels for those isoenzymes. Choi et al. [151] found expression levels of the PRKCI gene, encoding atypical iota isoenzyme of the $\mathrm{PKC}$ family, increased in the PFC of suicide victims as compared to non-suicide controls. One of the substrates for phosphorylation by protein kinase $C$, myristoylated alaninerich $\mathrm{C}$ kinase substrate (MARCKS), involved in neurotransmitter release and re-uptake, was postulated to play a role in mood disorders [152]. According to another study by Pandey and colleagues [153], protein levels of MARCKS were significantly increased in the membrane fraction of the PFC and the HIP obtained from depressed suicide subjects as compared to normal controls. The PKCmediated MARCKS phosphorylisation was also determined, and found significantly decreased in the membrane fraction of the PFC and the HIP obtained from both depressed and non-depressed suicide subjects. The authors suggest a decrease in MARCKS phosphorylisation may be a common feature of suicide victims, independent of the psychiatric diagnoses.

\section{Transcription factor CREB}

Activation of PKA, as well as PKC, phosphorylates several transcription factors, which then influence gene expression. Cyclic AMP response element binding protein 
(CREB) is a transcription factor, which has been implicated in the pathophysiology of suicide. Odagaki et al. [154] quantified the level of CREB in the PFC of depressed suicide victims by Western blotting. They observed a significant increase in the levels of CREB, both in total and phosphorylisated forms in brains of depressed victims compared to those of control subjects. The increase was observed specifically in antidepressant-free subjects, but not in the antidepressant-treated subjects, which suggests the role of cAMP signaling system in the therapy with antidepressants. Young and colleagues [155] reported increased numbers of phosphorylated CREB stained cells in several amygdalar nuclei in subjects who had died by suicide. On the other hand, Dwivedi et al. [142] reported the protein expression of CREB was significantly decreased in the nuclear fractions of both the PFC and the HIP obtained from suicide victims compared with control subjects. This was reflected by a decrease in the mRNA levels of CREB, as well as in the CRE-DNA binding activity, as measured in the nuclear fractions of both the PFC and the HIP. In accordance with these findings, Pandey and colleagues [156] reported a specific decrease in CRE-DNA binding and the mRNA as well as protein expression of CREB in the PFC of teenage suicide victims. However, they did not find any significant differences in the HIP CREB levels between teenage suicides and controls.

\section{Cytokines}

Cytokines are small cell-signaling protein molecules which serve as immuno-modulating agents. Changes in the immune system have been suggested to play a role in depression and suicidality, following observations of a negative influence of IFN-alpha on patients' mood [157,158], as well as of altered levels of pro- and anti-inflammatory cytokines in the serum [159-161] or the CSF of depressed patients [162,163]. What is more, Lindqvist et al. [164] found IL-6 level in CSF was significantly higher in suicide attempters than in healthy control subjects. The number of post-mortem studies focusing on cytokines is limited. However, Steiner et al. [165] found microgiliosis, one of the elements of immunological activation of the brain tissue, to be increased in the post-mortem brains of suicide victims diagnosed with affective disorders and schizophrenia. Tonelli and colleagues [166] described increased mRNA expression of IL-4 and IL-3 in the orbitofrontal cortex of female victims of suicide, as well as of IL-13 in PFC of male suicide victims compared with control subjects. Pandey et al. [167] reported significantly increased mRNA and protein expression levels of IL- $1 \beta$, IL- 6 , and TNF- $\alpha$ in Brodmann area 10 of teenage suicide victims as compared with normal control subjects Table 3 summarizes the findings regarding the role of cell-signalling in suicide.

\section{Neural plasticity}

\section{Neurotrophic factors}

Neurotrophic factors are a family of proteins that induce the survival, development, and functional differentiation of neurons [168], which includes among others nerve growth factor (NGF), brain-derived neurotrophic factor (BDNF), glial cell line-derived neurotrophic factor (GDNF), its family ligands neurturin (NTN), persephin (PSP), and artemin (ARTN), neurotrophin-3 (NT-3), and neurotrophin-4 (NT-4). The expression of BDNF is regulated by $\mathrm{CREB}$ through $\mathrm{Ca} 2+$ and the cAMP response element within exon 3 of BDNF. Given that a change in CREB levels has been shown in the post-mortem brains of suicide victims (see above), and the treatment with antidepressants causes an increase of BDNF in the brain [169], it has been hypothesized that depression and/or suicide may be associated with a decreased level of BDNF. Furthermore, neurotrophic factors have been discussed in the etiology of several other neuropsychiatric disorders such as schizophrenia and dementia $[170,171]$. Dwivedi and colleagues [172] determined the protein and mRNA expression levels of BDNF in the PFC and the HIP, finding them both to be significantly decreased in suicide victims compared with controls. According to Karege et al. [173], the levels of BDNF and NT-3 in the HIP and PFC of medication-free suicidal subjects were significantly decreased in comparison with controls. Interestingly, in suicide victims treated either with antipsychotic or antidepressant drugs, neurotrophine levels were not significantly different from those in nonsuicide controls. To further support a role of BDNF in suicidality, two genetic studies, including a study by Sarchiapone et al. [174], as well as a meta-analisys by Zai an colleagues [175], implicate an association between functional SNP (rs6265) of the BDNF gene and suicidal behaviour. The SNP results in (Val) to (Met) substitution in the proBDNF protein at codon 66, and is thought to be associated with low BDNF levels in psychiatric disorders. In contrast, de Luca and colleagues [176], who analyzed the BDNF Val66Met polymorphism in suicide completers and the parent-of origin effect $(\mathrm{POE})$ in suicide attempters, found no evidence for allelic imbalance or POE of BDNF for suicidal behaviour. Dwivedi et al. [172] measured the protein and mRNA expression of the TrkB receptor, a member of a family of tyrosine kinases with the highest affinity to the binding of BDNF. Out of the two known isoforms, the protein and mRNA expression levels of the full-length the TrkB receptors, but not their truncated isoform, were found significantly decreased in the PFC and in the HIP of suicide subjects. Ernst and colleagues [177] looked at a truncated splice variant of the TrkB (TrkB.T1), the only isoform expressed in astrocytes under normal conditions. They found that 10 out of 28 examined brain probes from 
Table 3 Cell-signalling in suicide

\begin{tabular}{|c|c|c|c|c|}
\hline \multicolumn{3}{|l|}{ System element } & \multirow{2}{*}{$\begin{array}{l}\text { Change } \\
\text { decreased }\end{array}$} & \multirow{2}{*}{$\begin{array}{l}\text { Location } \\
\text { PFC, HIP }\end{array}$} \\
\hline Adenylate cyclase & Protein kinase $\mathrm{A}$ & Enzyme activity & & \\
\hline & & Enzyme subunits RII, C3 levels & decreased & PFC, adult suicides \\
\hline & & $\begin{array}{l}\text { Enzyme subunits Rkt, } \\
\text { R113 levels }\end{array}$ & decreased & PFC, teenage suicides \\
\hline & & Enzyme substrate Rap- 1 & reduced activation & PFC, HIP \\
\hline & Second messenger & cAMP level & increased & $\mathrm{PC}, \mathrm{CN}$ \\
\hline & cAMP effector & Epac-2 level & increased & PFC, HIP \\
\hline & & CREB level & decreased & PFC, HIP \\
\hline & & & increased & $\begin{array}{l}\text { PFC, antidepressants-free } \\
\text { subjects }\end{array}$ \\
\hline & & & $\begin{array}{l}\text { increased density of CREB } \\
\text { stained cells }\end{array}$ & AN \\
\hline \multirow[t]{3}{*}{ Phospholipase C } & Protein kinase $C$ & Enzyme activity & decreased & PFC, HIP, teenage suicides \\
\hline & & Enzyme substrate MARCKS & $\begin{array}{l}\text { increased concentration, } \\
\text { decreased phosphorylation }\end{array}$ & PFC, HIP \\
\hline & Second messenger & IP3 level & increased & $\mathrm{HIP}, \mathrm{CN}$ \\
\hline \multirow[t]{6}{*}{ Cytokines } & Interleukins & IL-1 $\beta$ level & increased & $\mathrm{FC}$, teenage suicide \\
\hline & & IL-3 level & increased & PC, female suicides \\
\hline & & IL-4 level & increased & FC, female suicides \\
\hline & & IL-6 level & increased & PC, teenage suicide \\
\hline & & IL-13 level & increased & PC, male suicides \\
\hline & TNF-Family & TNF-a level & increased & PC, teenage suicide \\
\hline
\end{tabular}

suicide completers demonstrated significant decreases of TrkB.T1 in the Brodmann areas 8 and 9, a result not accounted for by substance abuse comorbidity or by reduction in astrocyte number. Moreover, it was found that the methylation of $2 \mathrm{CpG}$ dinucleotides, sites 2 and 5 of the TrkB promoter, is associated with the decreased expression of TrkB.T1.

The levels of the whole blood glial cell line-derived neurotrophic factor (GDNF) has been shown to be decreased in remitted patients with mood disorders [178] and one post-mortem study showed an increase in GDNF concentration in the $\mathrm{PC}$ of patients with depressive disorder [44], therefore suggesting its involvement in the pathophysiology of mood disorders and suicidality. Furthermore, both human and animal model have shown that different antidepressants cause an acute activation of protein tyrosine kinase (PTK) and extracellular signalregulated kinase (ERK), leading to the activation of CREB and resulting in an increase of the GDNF production [179-181]. Otsuki et al. [182] used qRT-PCR in peripheral blood cells of patients with major depressive and bipolar disorders to measure the expression levels of mRNAs of different neurotrophic factors. They reported a reduced expression of GDNF, ARTN, and NT-3 mRNAs in patients with current major depressive disorder. Altered expressions of these mRNAs were found neither in remitted patients with depressive disorder, nor in bipolar patients.

\section{Polyamins}

Polyamins, including putrescine, spermidine and spermine, are low molecular weight aliphatic amines involved in cell proliferation, apoptosis, immunity and oxidative stress response [183-185]. Changes in the expression of the polyamines and their metabolic enzymes have been postulated in different mental disorders, including suicidal behaviour [186]. Alterations in the expression of polyamine-related genes were identified using post-mortem brain tissue from suicide completers. Sequiera et al. [187] looked at the spermine/spermidine $\mathrm{N}(1)$ - acetyltransferase gene (SSAT), encoding the rate-limiting enzyme in the catabolism of polyamines. They found that an allele of a single nucleotide polymorphism (SNP) rs6526342 showed higher frequency among suicide cases. The authors suggest this SNP allele, located in the SSAT polyamine- responsive element regulatory region (SSAT342A/C), which demonstrates a significant effect on SSAT brain expression levels, may increase the predisposition to suicide. To further support this, Fiori et al. [188] showed that suicide completers who possessed the haplotype containing the risk allele for the very same SNP (rs6526342) demonstrated decreased SAT1 expression in Brodmann areas 4, $8 / 9$ and 11. They also identified three other polymorphisms - an insertion/deletion (rs6151267), and two SNPs (rs6526342 and rs928931) - located in the promoter region of SAT1, which were found to be involved in the 
regulation of gene expression and, according to the authors, might thus provide a mechanism for the decreased SAT1 expression observed in suicide completers. A reduction in spermine/spermidine $\mathrm{N}(1)$-acetyltransferase gene expression in cortical regions of individuals who have died by suicide was confirmed by Klempan et al. [189] and Guipponi et al. [190]. The latter study does not support a role of the rs6526342 SNP in suicide, but highlights the importance of epigenetic factors influencing the level of SAT1 expression, a conclusion drawn also by Fiori and Turecki [191]. Global gene expression profiling of the polyamine system in suicide completers by Fiori and colleagues [192] identified 14 genes displaying differential expression. These included spermidine/spermine N1acetyltransferase, spermine oxidase, spermine synthase, S-adenosylmethionine decarboxylase, ornithine decarboxylase antizymes 1 and 2, arginase II, aldehyde dehydrogenase 3 family, member A2, brain creatine kinase, mitochondrial creatine kinase 1, glycine amidinotransferase, glutamicoxaloacetic transaminase 1 , and arginyl-tRNA synthetaselike genes. Since many of these genes displayed altered expression across several brain regions, the authors concluded that a dysregulated polyamine metabolism is a widespread phenomenon in the brains of suicide completers. In another study, Fiori et al. [193] genotyped 1255 French-Canadian individuals for the 63 polymorphisms, spread across 1074 four polyaminergic genes. The group was followed-up longitudinally for 22 years. The authors found an association between suicide attempts and polymorphisms in SAT1 and the OATL1 genes. Additionally, different genetic variants of SAT1 were also associated with anxiety and mood disorders, conditions linked to suicidal behaviour. Taking into consideration a considerable amount of evidence linking changes in the polyamine metabolism with suicide, Chen et al. [194] hypothesised levels of spermine, spermidine and putrescine would be different in the brains of suicide victims. To this end, they used a GC-MS method developed specifically for the measurement of spermidine and putrescine levels in post-mortem brain tissue [195], to compare the probes derived from suicide completers and controls.
In correlation with the conclusions drawn from the previous genetic studies, both putrescine and spermidine levels were found significantly elevated in the brain of suicide victims with major depression.

Table 4 gives an overview of the changes in neural plasticity observed in suicide victims.

\section{Neuroendocrinology}

Abnormalities in HPA axis have been postulated both in mood disorders and suicide. On the one hand, most patients with depression have been shown to present with hypercortisolemia both in plasma and CSF, increased cortisol response to adrenocorticotropic hormone (ACTH) and a deficient feedback mechanism, reflected in an abnormal dexamethasone suppression test [11] as well as by enlarged pituitary and adrenal glands [196-198]. On the other hand, a large amount of evidence linking HPA axis dysfunction to suicidality has been published to date. Yerevanian et al. [199] found that DST non-supressors with unipolar depression were significantly more likely to commit suicide than DST suppressors. Similar results were reported by Coryell and Schlesser [200] in a 15years long follow-up study of patients with major depressive disorder or a depressed type of schizoaffective disorder. As for suicide attempts, some studies report an association with DST non-suppression [201,202], while others do not $[203,204]$. This suggests HPA axis disturbances may be more strongly related to suicide completion rather than just attempts. Thus, studying the elements of this axis in brain probes from suicide subjects is another interesting area. Raadsheer et al. [205] reported that the mean total number of $\mathrm{CRH}$-expressing neurons and of CRH neurons co-expressing AVP in hypothalamic paraventricular nucleus (PVN) was significantly higher in depressed subjects than in the control group. Merali et al. [206,207] found CRHimmunoreactivity levels among suicides were elevated in the LC and in frontopolar, dorsolateral prefrontal (DMPFC) and ventromedial prefrontal cortices, but reduced at the dorsovagal complex (DVC). Austin et al. [208] hypothesized that CRH levels in suicide victims

Table 4 Changes in neural plasticity in suicide

\begin{tabular}{|c|c|c|c|c|}
\hline \multicolumn{3}{|l|}{ System element } & \multirow{2}{*}{$\begin{array}{l}\text { Change } \\
\text { decreased }\end{array}$} & \multirow{2}{*}{$\begin{array}{l}\text { Location } \\
\text { PFC, HIP, antidepressants- } \\
\text { free subjects }\end{array}$} \\
\hline Neurotrophic factors & Neurotrophins & BDNF level & & \\
\hline & & NT-3 level & decreased & $\begin{array}{l}\text { PFC, HIP, antidepressants- } \\
\text { free subjects }\end{array}$ \\
\hline & BDNF-binding receptor & TrkB receptor concentration & decreased & PFC, HIP \\
\hline & & $\begin{array}{l}\text { TrkB.T1 truncated form } \\
\text { receptor concentration }\end{array}$ & decreased & PFC \\
\hline \multirow[t]{2}{*}{ Polyamins } & Putrescine levels & & increased & G \\
\hline & Spermidine levels & & increased & G \\
\hline
\end{tabular}


would be increased also beyond the $\mathrm{HTH}$, in specific brainstem regions. They next tested this with help of radioimmuno-cytochemistry, using primary antiserum to $\mathrm{CRH}$ and a ([125])I-IgG secondary antibody. They reported an increased level of CRH-immunoreactivity in the LC, in the median raphe and in the caudal dorsal raphe of depressed suicide subjects compared to controls. In conditions of chronic hypersecretion of $\mathrm{CRH}$, due to downregulation, a reduced number of CRF receptor binding sites should be present. Accordingly, Nemeroff and colleagues [209] described a marked reduction in the number of CRF binding sites in the FC of suicide victims compared with controls. Subsequently, the mRNA levels of CRH1, but not CRH2 receptors for corticotropin were found decreased in suicide brains [206]. What is more, a shift in CRH1:CRH2 mRNA ratio was also reported in pituitaries of suicide subjects [210]. The feedback regulation of the HPA axis by glucocorticosteroids is mediated through two intracellular receptors, known as mineralocorticoid (MRs) and glucocorticoid (GRs) receptors. GRs, which are believed to play an important role in the regulation of stress response, have been studied in the peripheral tissues of depressed patients [211], who present with a reduced GRs function sometimes referred to as GR resistance, as well as in post-mortem brains of patients with different psychiatric disorders [212,213], which show decreased levels of GRs in comparison to normal controls. The above described findings indicate that there is a need to also examine a possible role of GRs in the pathology of suicide. To date, one study by Lopez and colleagues [214] focused on the localization of glucocorticoid receptor (GR) mRNA and proopiomelanocortin (POMC) mRNA in anterior pituitaries of suicide subjects. The analysis of the corticotrophic cell clumps showed that the suicide victims had a higher POMC mRNA density per cell and a larger corticotrophic cell size than controls, however no differences in GR mRNA were detected between the two groups. McGowan et al. [215] reported that the expression of total glucocorticoid receptor mRNA was significantly reduced in suicide victims with a history of childhood abuse when compared to suicide victims who did not suffer childhood abuse or to controls. Supriyanto et al. [216] tested a possible association between suicide and polymorphisms of the glucocorticoid receptor (NR3C1), the mineralocorticoid receptor (NR3C2), and the FK506 binding protein 5 (FKBP5) genes, all of them involved in HPA axis regulation. The authors found that the distributions of TT, TC, and GT haplotypes of the FKBP5 gene (comprised of rs3800373 and rs1360780) in completed suicide and control groups were significantly different. Since the FK506 binding protein 5 interacts functionally with mature corticoid receptor hetero-complexes, this confirms a crucial role of the HPA axis in suicidality. However, no significant differences in genotypic distribution of any single SNP in the three genes in question were observed between the individuals who completed suicide and control groups Table 5.

\section{Discussion}

\section{Limitations}

Post-mortem studies on brain tissue have a number of limitations. One of them is the relatively short period of time, within which the samples should be collected. For example, the levels of dihydropyrimidinase-related protein-2 were found to decrease within $6 \mathrm{~h}$ after death [217]. Thus, the post-mortem interval should ideally not exceed 6 hours, which sometimes can be very hard to achieve. Another problem is the small sample size, which significantly limits the possibility to generate data fit for detailed statistical analysis, especially regarding genetics. Only further improvement in brain collection programs can help to confirm the results of previous pilot studies based on small groups of subjects. The issue is further complicated by an considerable overlap between psychiatric disorders, all of which might alone be associated with certain neurobiological abnormalities, and suicide. With the limited availability of post-mortem samples from psychiatric patients who died of natural causes, it is very difficult to examine if the neurobiological abnormalities in the post-mortem brains are related to suicidality or rather to the psychiatric diagnoses. Hence, there is a need for comparison studies of samples obtained from suicide victims with a particular diagnosis, and those taken from subjects with exactly the same diagnosis, who died of natural causes. Another important problem is the influence of pharmacological and other therapies used in psychiatric patients on brain biology. Thus, it is difficult to distinguish

Table 5 HPA axis in suicide

\begin{tabular}{|c|c|c|c|c|}
\hline \multicolumn{3}{|c|}{ System element } & \multirow{2}{*}{$\begin{array}{l}\text { Change } \\
\text { increased }\end{array}$} & \multirow{2}{*}{$\begin{array}{l}\text { Location } \\
\mathrm{LC}, \mathrm{DLPFC}, \mathrm{FPC}, \mathrm{VMPFC}, \mathrm{Cl}\end{array}$} \\
\hline Hormones & $\mathrm{CRH}$ levels & & & \\
\hline & & & decreased & DVC \\
\hline & POMC mRNA level & & increased & aPIT \\
\hline \multirow[t]{3}{*}{ Receptors } & CRH-receptors & receptor density & decreased & FC \\
\hline & $\mathrm{CRH1}$-receptor mRNA level & decreased & G & $\mathrm{CRH1-receptor} \mathrm{mRNA} \mathrm{level}$ \\
\hline & $\mathrm{CRH} 1 / \mathrm{CRH} 2$ receptor ratio & decreased & PIT & $\mathrm{CRH} 1 / \mathrm{CRH} 2$ receptor ratio \\
\hline
\end{tabular}


neurobiological factors independently associated with suicidality and not related to comorbid psychiatric disorders or caused by psychiatric treatment. Last but not least, the role of obtaining a very detailed psychological history should never be underestimated. The use of validated methods to reconstruct psychiatric history by means of extensive proxy-based interviews [218] is indispensable in order to eliminate possible confounding variables influencing the results, such as the history of childhood abuse, other trauma, personality disorders, but also somatic diagnoses.

\section{Future possibilities}

Post-mortem studies of suicidality provide many possibilities for widening our knowledge of the underlying neuropathology and of the influence of medication and substance abuse, as well as for constructing and testing different clinical hypotheses. Several interesting new research directions of post-mortem studies are conceivable for the future, including innovative genetic and epigenetic studies with the use of new data bases and new brain collection programs. Another unique possibility is the comparison of neurobiological factors characteristic for suicide in the samples representing particular psychiatric disorders, as described above. The same goes for differentiating between neurobiological abnormalities related to suicidal behaviour and those associated with completed suicide. Another interesting possibility is the description of the effects of different psychiatric drugs, their actions on genes expression, protein levels and neuro-receptors, and their efficacy in preventing suicide. Last but not least, the impact of chronic or acute substance intoxication on the brain neurobiology and its influence on the suicide risk could also be further researched in post-mortem studies.

\section{Conclusions}

Studies on post-mortem brain tissue provide numerous possibilities for a deeper insight into the neurobiology of different psychiatric disorders, including suicidal behaviour. With new methods being now introduced to improve the reliability of results, genetic information being openly available for analyses and comparisons and the brain tissue banks being founded and expanded, the post-mortem studies are likely to grow in number and further develop in future.

\footnotetext{
Abbreviations

AN: Amygdalar nuclei; BD: Bipolar disorder; CN: Caudate nuceus; DLPFC: Dorsolateral prefrontal cortex; DVC: Dorsovagal complex; FC: Frontal cortex; FPC: Frontopolar cortex; G: Global; HIP: Hippocampus; HTH: Hypothalamus; LC: Locus coeruleus; LS: Limbic system; MD: Major depression; NA: Nucleus accumbens; NC: Not characterised; OC: Occipital cortex; P: Putamen; PIT: Pituitary; aPIT: Anterior pituitary; PFC: Prefrontal cortex; RN: Raphe nuclei; SCH: Schizophrenia; TC: Temporal cortex; VMPFC: Ventromedial prefrontal cortex.
}

\section{Competing interests}

JT has obtained financial support (e.g. lecture honoraria, grants for resarch projects and scientific meetings, advisory-board membership) from Actelion, AstraZeneca, Bristol-Meyers Squibb, Ever Neuro Pharma, Janssen-Cilag, Lilly, Lundbeck, Medice Arzneimittel Pütter, Merz Pharmaceuticals, Novartis Pharma, Pfizer Pharma, Roche, Servier, Shire. The other authors declare, that they do not have any competing interests.

\section{Authors' contributions}

KF made substantial contributions to conception and design of the article, was involved in drafting the manuscript and revising it critically for important intellectual content. BS made substantial contributions to conception of the article, was involved in revising it critically for important intellectual content. TMM made substantial contributions to conception of the article and was involved in revising it critically for important intellectual content. JT initiated the work on this manuscript and made substantial contributions to its conception and design; he was involved in drafting and revising it critically for important intellectual content. $A B$ initiated the work on this manuscript and made substantial contributions to its conception and design; he was involved in drafting and revising it critically for important intellectual content. All authors read and approved the final manuscript.

\section{Author details}

${ }^{1}$ Department of Psychiatry, University of Rostock, Gehlsheimerstrasse 20, 18147, Rostock, Germany. ${ }^{2}$ College of Medicine, Swansea University, Singleton Park, Swansea SA2 PP, UK. ${ }^{3}$ Institute of Forensic Medicine, University of Rostock, St.-Georg-Strasse 108, 18055, Rostock, Germany.

Received: 26 September 2012 Accepted: 15 February 2013 Published: 23 April 2013

\section{References}

1. Conwell Y, Duberstein PR, Cox C, Herrmann JH, Forbes NT, Caine ED: Relationships of age and axis I diagnoses in victims of completed suicide: a psychological autopsy study. Am J Psychiatry 1996, 153:1001-1008.

2. Harris EC, Barraclough B: Suicide as an outcome for mental disorders. A meta- analysis. Br J Psychiatry 1997, 170:205-228.

3. Henriksson MM, Aro HM, Marttunen MJ, Heikkinen ME, Isometsa ET, Kuoppasalmi Kl, Lonnqvist JK: Mental disorders and comorbidity in suicide. Am J Psychiatry 1993, 150:935-940.

4. Westrin A: Stress system alterations and mood disorders in suicidal patients. A review. Biomed Pharmacother 2000, 54:142-145.

5. McGirr A, Turecki G: The relationship of impulsive aggressiveness to suicidality and other depression-linked behaviors. Curr Psychiatry Rep 2007, 9:460-466

6. Scott KM, Hwang I, Chiu WT, Kessler RC, Sampson NA, Angermeyer M Beautrais A, Borges G, Bruffaerts R, de Graaf R, Florescu S, Fukao A, Haro JM, Hu C, Kovess V, Levinson D, Posada-Villa J, Scocco P, Nock MK: Chronic physical conditions and their association with first onset of suicidal behavior in the world mental health surveys. Psychosom Med 2010, 72:712-719.

7. Beck AT, Steer RA, Beck JS, Newman CF: Hopelessness, depression, suicidal ideation, and clinical diagnosis of depression. Suicide Life Threat Behav 1993, 23:139-145.

8. Au AC, Lau S, Lee MT: Suicide ideation and depression: the moderation effects of family cohesion and social self-concept. Adolescence 2009, 44:851-868.

9. Hafner $\mathrm{H}$ : [The epidemiology of suicide and attempted suicide]. Psychiatr Neurol Med Psychol (Leipz) 1989, 41:449-475.

10. Asberg M, Traskman L, Thoren P: 5-HIAA in the cerebrospinal fluid. A biochemical suicide predictor? Arch Gen Psychiatry 1976, 33:1193-1197.

11. Nordstrom P, Samuelsson M, Asberg M, Traskman-Bendz L, Aberg-Wistedt A, Nordin C, Bertilsson L: CSF 5-HIAA predicts suicide risk after attempted suicide. Suicide Life Threat Behav 1994, 24:1-9.

12. Pandey GN, Pandey SC, Dwivedi Y, Sharma RP, Janicak PG, Davis JM: Platelet serotonin-2A receptors: a potential biological marker for suicidal behavior. Am J Psychiatry 1995, 152:850-855.

13. van Praag HM: CSF 5-HIAA and suicide in non-depressed schizophrenics. Lancet 1983, 2:977-978.

14. McGirr A, Diaconu G, Berlim MT, Pruessner JC, Sable R, Cabot S, Turecki G: Dysregulation of the sympathetic nervous system, hypothalamic- 
pituitary-adrenal axis and executive function in individuals at risk for suicide. J Psychiatry Neurosci 2010, 35:399-408.

15. Sunnqvist C, Westrin A, Traskman-Bendz L: Suicide attempters: biological stressmarkers and adverse life events. Eur Arch Psychiatry Clin Neurosci 2008, 258:456-462.

16. Kamali M, Saunders EF, Prossin AR, Brucksch CB, Harrington GJ, Langenecker SA, Mclnnis MG: Associations between suicide attempts and elevated bedtime salivary cortisol levels in bipolar disorder. J Affect Disord 2012, 136:350-358.

17. Greenhalgh T: How to read a paper: Papers that summarise other papers systematic reviews and meta-analyses). BMJ 1997, 315:672-675.

18. Schmitt A, Parlapani E, Bauer M, Heinsen H, Falkai P: Is brain banking of psychiatric cases valuable for neurobiological research? Clinics (Sao Paulo) 2008, 63:255-266.

19. Monoranu CM, Grunblatt E, Bartl J, Meyer A, Apfelbacher M, Keller D, Michel TM, Al- Saraj S, Schmitt A, Falkai P, Roggendorf W, Deckert J, Ferrer I, Riederer P: Methyl- and acetyltransferases are stable epigenetic markers postmortem. Cell Tissue Bank 2011, 12:289-297.

20. Grunblatt E, Proft F, Apfelbacher M, Deckert J, Roggendorf W, Riederer P, Monoranu CM: Brain tryptophan rather than $\mathrm{pH}$-value is altered as consequence of artificial postmortem interval and storage conditions. Neurochem Int 2010, 57:819-822.

21. Bell JE, Alafuzoff I, Al-Sarraj S, Arzberger T, Bogdanovic N, Budka H, Dexter DT, Falkai P, Ferrer I, Gelpi E, Gentleman SM, Giaccone G, Huitinga I, Ironside JW, Klioueva N, Kovacs GG, Meyronet D, Palkovits M, Parchi P, Patsouris E, Reynolds R, Riederer P, Roggendorf W, Seilhean D, Schmitt A, Schmitz P, Streichenberger N, Schwalber A, Kretzschmar H: Management of a twentyfirst century brain bank: experience in the BrainNet Europe consortium. Acta Neuropathol 2008, 115:497-507.

22. Sequeira A, Kim C, Seguin M, Lesage A, Chawky N, Desautels A, Tousignant M, Vanier C, Lipp O, Benkelfat C, Rouleau G, Turecki G: Wolfram syndrome and suicide: Evidence for a role of WFS1 in suicidal and impulsive behavior. Am J Med Genet B Neuropsychiatr Genet 2003, 119B:108-113.

23. Swift RG, Sadler DB, Swift M: Psychiatric findings in Wolfram syndrome homozygotes. Lancet 1990, 336:667-669.

24. Kunugi $H$, Hashimoto $R$, Yoshida $M$, Tatsumi $M$, Kamijima $K$ : A missense polymorphism (S205L) of the low-affinity neurotrophin receptor p75NTR gene is associated with depressive disorder and attempted suicide. Am J Med Genet B Neuropsychiatr Genet 2004, 129B:44-46.

25. Iwamoto K, Bundo M, Kato T: Altered expression of mitochondria-related genes in postmortem brains of patients with bipolar disorder or schizophrenia, as revealed by large-scale DNA microarray analysis. Hum Mol Genet 2005, 14:241-253.

26. Konradi C: Gene expression microarray studies in polygenic psychiatric disorders: applications and data analysis. Brain Res Brain Res Rev 2005, 50:142-155

27. Must A, Koks S, Vasar E, Tasa G, Lang A, Maron E, Vali M: Common variations in $4 p$ locus are related to male completed suicide. Neuromolecular Med 2009, 11:13-19.

28. Sequeira A, Klempan T, Canetti L, Ffrench-Mullen J, Benkelfat C, Rouleau GA, Turecki G: Patterns of gene expression in the limbic system of suicides with and without major depression. Mol Psychiatry 2007, 12:640-655.

29. Glare EM, Divjak M, Bailey MJ, Walters EH: beta-Actin and GAPDH housekeeping gene expression in asthmatic airways is variable and not suitable for normalising mRNA levels. Thorax 2002, 57:765-770.

30. Shi Q, Pavey ES, Carter RE: Bonferroni-based correction factor for multiple, correlated endpoints. Pharm Stat 2012, 11:300-309.

31. Yang G, Gong YD, Gong K, Jiang WL, Kwon E, Wang P, Zheng H, Zhang XF, Gan WB, Zhao NM: Reduced synaptic vesicle density and active zone size in mice lacking amyloid precursor protein (APP) and APP-like protein 2. Neurosci Lett 2005, 384:66-71.

32. Ferguson GD, Herschman HR, Storm DR: Reduced anxiety and depressionlike behavior in synaptotagmin IV (-/-) mice. Neuropharmacology 2004 , 47:604-611.

33. Sequeira A, Mamdani F, Ernst C, Vawter MP, Bunney WE, Lebel V, Rehal S, Klempan T, Gratton A, Benkelfat C, Rouleau GA, Mechawar N, Turecki G: Global brain gene expression analysis links glutamatergic and GABAergic alterations to suicide and major depression. PLoS One 2009, 4:e6585.

34. Kuloglu M, Ustundag B, Atmaca M, Canatan H, Tezcan AE, Cinkilinc N: Lipid peroxidation and antioxidant enzyme levels in patients with schizophrenia and bipolar disorder. Cell Biochem Funct 2002, 20:171-175.
35. Thalmeier A, Dickmann M, Giegling I, Schneider B, MH A, Maurer K Schnabel A, Kauert G, Moller HJ, Rujescu D: Gene expression profiling of post-mortem orbitofrontal cortex in violent suicide victims. Int $J$ Neuropsychopharmacol 2008, 11:217-228.

36. Kim S, Choi KH, Baykiz AF, Gershenfeld HK: Suicide candidate genes associated with bipolar disorder and schizophrenia: an exploratory gene expression profiling analysis of post-mortem prefrontal cortex. BMC Genomics 2007, 8:413.

37. Sibille E, Arango V, Galfalvy HC, Pavlidis P, Erraji-Benchekroun L, Ellis SP, John Mann J: Gene expression profiling of depression and suicide in human prefrontal cortex. Neuropsychopharmacology 2004, 29:351-361.

38. Wilkins MR, Sanchez JC, Gooley AA, Appel RD, Humphery-Smith I, Hochstrasser DF, Williams KL: Progress with proteome projects: why all proteins expressed by a genome should be identified and how to do it. Biotechnol Genet Eng Rev 1996, 13:19-50.

39. Hunnerkopf R, Grassl J, Thome J: [Proteomics: biomarker research in psychiatry]. Fortschr Neurol Psychiatr 2007, 75:579-586.

40. Schlicht K, Büttner A, Siedler F, Scheffer B, Zill P, Eisenmenger W, Ackenheil $\mathrm{M}$, Bondy B: Comparative proteomic analysis with postmortem prefrontal cortex tissues of suicide victims versus controls. J Psychiatr Res 2007, 41:493-501.

41. Eng LF, Ghirnikar RS, Lee YL: Glial fibrillary acidic protein: GFAP-thirty-one years (1969-2000). Neurochem Res 2000, 25:1439-1451.

42. Webster MJ, Knable MB, Johnston-Wilson N, Nagata K, Inagaki M, Yolken RH: Immunohistochemical localization of phosphorylated glial fibrillary acidic protein in the prefrontal cortex and hippocampus from patients with schizophrenia, bipolar disorder, and depression. Brain Behav Immun 2001, 15:388-400.

43. De Leo ME, Borrello S, Passantino M, Palazzotti B, Mordente A, Daniele A, Filippini V, Galeotti T, Masullo C: Oxidative stress and overexpression of manganese superoxide dismutase in patients with Alzheimer's disease. Neurosci Lett 1998, 250:173-176.

44. Michel TM, Frangou S, Camara S, Thiemeyer D, Jecel J, Tatschner T, Zoechling R, Grunblatt E: Altered glial cell line-derived neurotrophic factor (GDNF) concentrations in the brain of patients with depressive disorder: a comparative post-mortem study. Eur Psychiatry 2008, 23:413-420.

45. Michel TM, Thome J, Martin D, Nara K, Zwerina S, Tatschner T, Weijers HG, Koutsilieri $\mathrm{E}: \mathrm{Cu}, \mathrm{Zn}$ - and Mn-superoxide dismutase levels in brains of patients with schizophrenic psychosis. J Neural Transm 2004, 111:1191-1201.

46. Pae CU, Yoon SJ, Patkar A, Kim JJ, Jun TY, Lee C, Paik IH: Manganese superoxide dismutase (MnSOD: Ala-9Val) gene polymorphism and mood disorders: a preliminary study. Prog Neuropsychopharmacol Biol Psychiatry 2006, 30:1326-1329.

47. Ranjekar PK, Hinge A, Hegde MV, Ghate M, Kale A, Sitasawad S, Wagh UV, Debsikdar VB, Mahadik SP: Decreased antioxidant enzymes and membrane essential polyunsaturated fatty acids in schizophrenic and bipolar mood disorder patients. Psychiatry Res 2003, 121:109-122.

48. Brunner J, Bronisch T, Uhr M, Ising M, Binder E, Holsboer F, Turck CW: Proteomic analysis of the CSF in unmedicated patients with major depressive disorder reveals alterations in suicide attempters. Eur Arch Psychiatry Clin Neurosci 2005, 255:438-440.

49. Stockmeier CA, Shapiro LA, Dilley GE, Kolli TN, Friedman L, Rajkowska G: Increase in serotonin-1A autoreceptors in the midbrain of suicide victims with major depression-postmortem evidence for decreased serotonin activity. J Neurosci 1998, 18:7394-7401.

50. Matsubara S, Arora RC, Meltzer HY: Serotonergic measures in suicide brain: 5- HT1A binding sites in frontal cortex of suicide victims. J Neural Transm Gen Sect 1991, 85:181-194.

51. Arranz B, Eriksson A, Mellerup E, Plenge P, Marcusson J: Brain 5-HT1A, 5-HT1D, and 5-HT2 receptors in suicide victims. Biol Psychiatry 1994, 35:457-463.

52. Lowther S, De Paermentier F, Cheetham SC, Crompton MR, Katona CL, Horton RW: 5-HT1A receptor binding sites in post-mortem brain samples from depressed suicides and controls. J Affect Disord 1997 42:199-207.

53. Stockmeier CA, Dilley GE, Shapiro LA, Overholser JC, Thompson PA, Meltzer HY: Serotonin receptors in suicide victims with major depression. Neuropsychopharmacology 1997, 16:162-173.

54. Stockmeier CA, Howley E, Shi X, Sobanska A, Clarke G, Friedman L, Rajkowska G: Antagonist but not agonist labeling of serotonin-1A receptors is decreased in major depressive disorder. J Psychiatr Res 2009 , 43:887-894. 
55. Arango V, Underwood MD, Gubbi AV, Mann JJ: Localized alterations in pre- and postsynaptic serotonin binding sites in the ventrolateral prefrontal cortex of suicide victims. Brain Res 1995, 688:121-133.

56. Joyce JN, Shane A, Lexow N, Winokur A, Casanova MF, Kleinman JE: Serotonin uptake sites and serotonin receptors are altered in the limbic system of schizophrenics. Neuropsychopharmacology 1993, 8:315-336.

57. Gingrich JA, Hen R: Dissecting the role of the serotonin system in neuropsychiatric disorders using knockout mice. Psychopharmacology (Berl) 2001, 155:1-10

58. New AS, Gelernter J, Goodman M, Mitropoulou V, Koenigsberg H, Silverman J, Siever LJ: Suicide, impulsive aggression, and HTR1B genotype. Biol Psychiatry 2001, 50:62-65

59. Huang YY, Grailhe R, Arango V, Hen R, Mann JJ: Relationship of psychopathology to the human serotonin1B genotype and receptor binding kinetics in postmortem brain tissue. Neuropsychopharmacology 1999, 21:238-246.

60. Huang YY, Oquendo MA, Friedman JM, Greenhill LL, Brodsky B, Malone KM Khait V, Mann JJ: Substance abuse disorder and major depression are associated with the human 5-HT1B receptor gene (HTR1B) G861C polymorphism. Neuropsychopharmacology 2003, 28:163-169.

61. Stefulj J, Büttner A, Kubat M, Zill P, Balija M, Eisenmenger W, Bondy B, Jerne B: $5 \mathrm{HT}-2 \mathrm{C}$ receptor polymorphism in suicide victims. Association studies in German and Slavic populations. Eur Arch Psychiatry Clin Neurosci 2004, 254:224-227.

62. Stanley M, Mann JJ: Increased serotonin-2 binding sites in frontal cortex of suicide victims. Lancet 1983, 1:214-216.

63. Arango V, Ernsberger P, Marzuk PM, Chen JS, Tierney H, Stanley M, Reis DJ, Mann JJ: Autoradiographic demonstration of increased serotonin 5-HT2 and beta- adrenergic receptor binding sites in the brain of suicide victims. Arch Gen Psychiatry 1990, 47:1038-1047.

64. Arora RC, Meltzer HY: $3 \mathrm{H}$-imipramine binding in the frontal cortex of suicides. Psychiatry Res 1989, 30:125-135.

65. Mann JJ, Stanley M, McBride PA, McEwen BS: Increased serotonin2 and beta- adrenergic receptor binding in the frontal cortices of suicide victims. Arch Gen Psychiatry 1986, 43:954-959.

66. Pandey GN, Dwivedi Y, Rizavi HS, Ren X, Pandey SC, Pesold C, Roberts RC, Conley RR, Tamminga CA: Higher expression of serotonin 5-HT(2A) receptors in the postmortem brains of teenage suicide victims. Am J Psychiatry 2002, 159:419-429.

67. Turecki G, Briere R, Dewar K, Antonetti T, Lesage AD, Seguin M, Chawky N, Vanier C, Alda M, Joober R, Benkelfat C, Rouleau GA: Prediction of level of serotonin $2 \mathrm{~A}$ receptor binding by serotonin receptor $2 \mathrm{~A}$ genetic variation in postmortem brain samples from subjects who did or did not commit suicide. Am J Psychiatry 1999, 156:1456-1458.

68. Yates M, Leake A, Candy JM, Fairbairn AF, McKeith IG, Ferrier IN: 5HT2 receptor changes in major depression. Biol Psychiatry 1990, 27:489-496.

69. Crow TJ, Cross AJ, Cooper SJ, Deakin JF, Ferrier IN, Johnson JA, Joseph MH Owen F, Poulter M, Lofthouse R, et al: Neurotransmitter receptors and monoamine metabolites in the brains of patients with Alzheimer-type dementia and depression, and suicides. Neuropharmacology 1984, 23:1561-1569.

70. Lowther S, De Paermentier F, Crompton MR, Katona CL, Horton RW: Brain 5-HT2 receptors in suicide victims: violence of death, depression and effects of antidepressant treatment. Brain Res 1994, 642:281-289.

71. Owen F, Cross AJ, Crow TJ, Deakin JF, Ferrier IN, Lofthouse R, Poulter M: Brain 5- HT-2 receptors and suicide. Lancet 1983, 2:1256.

72. Rosel P, Arranz B, San L, Vallejo J, Crespo JM, Urretavizcaya M, Navarro MA Altered 5-HT(2A) binding sites and second messenger inositol trisphosphate (IP(3)) levels in hippocampus but not in frontal cortex from depressed suicide victims. Psychiatry Res 2000, 99:173-181.

73. Gross-Isseroff R, Dillon KA, Fieldust SJ, Biegon A: Autoradiographic analysis of alpha 1-noradrenergic receptors in the human brain postmortem. Effect of suicide. Arch Gen Psychiatry 1990, 47:1049-1053

74. Escriba PV, Ozaita A, Garcia-Sevilla JA: Increased mRNA expression of alpha2A- adrenoceptors, serotonin receptors and mu-opioid receptors in the brains of suicide victims. Neuropsychopharmacology 2004, 29:1512-1521

75. Shelton RC, Sanders-Bush E, Manier DH, Lewis DA: Elevated 5-HT 2A receptors in postmortem prefrontal cortex in major depression is associated with reduced activity of protein kinase A. Neuroscience 2009, 158:1406-1415.
76. Barnes NM, Sharp T: A review of central 5-HT receptors and their function. Neuropharmacology 1999, 38:1083-1152.

77. Giorgetti M, Tecott $\mathrm{LH}$ : Contributions of $5-\mathrm{HT}(2 \mathrm{C})$ receptors to multiple actions of central serotonin systems. Eur J Pharmacol 2004, 488:1-9.

78. Pandey GN, Dwivedi Y, Ren X, Rizavi HS, Faludi G, Sarosi A, Palkovits M: Regional distribution and relative abundance of serotonin $(2 \mathrm{c})$ receptors in human brain: effect of suicide. Neurochem Res 2006, 31:167-176.

79. Burns CM, Chu H, Rueter SM, Hutchinson LK, Canton H, Sanders-Bush E, Emeson RB: Regulation of serotonin-2C receptor G-protein coupling by RNA editing. Nature 1997, 387:303-308,

80. Gurevich I, Tamir H, Arango V, Dwork AJ, Mann JJ, Schmauss C: Altered editing of serotonin $2 \mathrm{C}$ receptor pre-mRNA in the prefrontal cortex of depressed suicide victims. Neuron 2002, 34:349-356.

81. Dracheva $\mathrm{S}$, Chin $\mathrm{B}$, Haroutunian V: Altered serotonin $2 \mathrm{C}$ receptor RNA splicing in suicide: association with editing. Neuroreport 2008, 19:379-382.

82. Wang Q, O'Brien PJ, Chen CX, Cho DS, Murray JM, Nishikura K: Altered G protein- coupling functions of RNA editing isoform and splicing variant serotonin2C receptors. J Neurochem 2000, 74:1290-1300.

83. Lappalainen J, Long JC, Virkkunen M, Ozaki N, Goldman D, Linnoila M: HTR2C Cys23Ser polymorphism in relation to CSF monoamine metabolite concentrations and DSM-III-R psychiatric diagnoses. Biol Psychiatry 1999, 46:821-826.

84. Stefulj J, Büttner A, Skavic J, Zill P, Balija M, Eisenmenger W, Bondy B, Jernej B: Serotonin 1B (5HT-1B) receptor polymorphism (G861C) in suicide victims: association studies in German and Slavic population. Am J Med Genet B Neuropsychiatr Genet 2004, 127B:48-50.

85. Videtic A, Peternelj TT, Zupanc T, Balazic J, Komel R: Promoter and functional polymorphisms of HTR2C and suicide victims. Genes Brain Behav 2009, 8:541-545.

86. Underwood MD, Khaibulina AA, Ellis SP, Moran A, Rice PM, Mann JJ, Arango $\checkmark$ : Morphometry of the dorsal raphe nucleus serotonergic neurons in suicide victims. Biol Psychiatry 1999, 46:473-483.

87. Boldrini M, Underwood MD, Mann JJ, Arango V: More tryptophan hydroxylase in the brainstem dorsal raphe nucleus in depressed suicides. Brain Res 2005, 1041:19-28.

88. Zill P, Büttner A, Eisenmenger W, Bondy B, Ackenheil M: Regional mRNA expression of a second tryptophan hydroxylase isoform in postmortem tissue samples of two human brains. Eur Neuropsychopharmacol 2004, $14: 282-284$

89. Zill P, Büttner A, Eisenmenger W, Moller HJ, Bondy B, Ackenheil M: Single nucleotide polymorphism and haplotype analysis of a novel tryptophan hydroxylase isoform (TPH2) gene in suicide victims. Biol Psychiatry 2004, 56:581-586

90. Ono H, Shirakawa O, Kitamura N, Hashimoto T, Nishiguchi N, Nishimura A, Nushida H, Ueno Y, Maeda K: Tryptophan hydroxylase immunoreactivity is altered by the genetic variation in postmortem brain samples of both suicide victims and controls. Mol Psychiatry 2002, 7:1127-1132.

91. Purselle DC, Nemeroff CB: Serotonin transporter: a potential substrate in the biology of suicide. Neuropsychopharmacology 2003, 28:613-619.

92. Mann JJ, Huang YY, Underwood MD, Kassir SA, Oppenheim S, Kelly TM, Dwork AJ, Arango $\mathrm{V}$ : A serotonin transporter gene promoter polymorphism (5-HTTLPR) and prefrontal cortical binding in major depression and suicide. Arch Gen Psychiatry 2000, 57:729-738.

93. Bligh-Glover W, Kolli TN, Shapiro-Kulnane L, Dilley GE, Friedman L, Balraj E, Rajkowska G, Stockmeier CA: The serotonin transporter in the midbrain of suicide victims with major depression. Biol Psychiatry 2000, 47:1015-1024

94. Parsey RV, Hastings RS, Oquendo MA, Hu X, Goldman D, Huang YY, Simpson N, Arcement J, Huang Y, Ogden RT, Van Heertum RL, Arango V, Mann JJ: Effect of a triallelic functional polymorphism of the serotonintransporter-linked promoter region on expression of serotonin transporter in the human brain. Am J Psychiatry 2006, 163:48-51.

95. Shioe K, Ichimiya T, Suhara T, Takano A, Sudo Y, Yasuno F, Hirano M, Shinohara M, Kagami M, Okubo Y, Nankai M, Kanba S: No association between genotype of the promoter region of serotonin transporter gene and serotonin transporter binding in human brain measured by PET. Synapse 2003, 48:184-188.

96. Zupanc T, Pregelj P, Tomori M, Komel R, Paska AV: No association between polymorphisms in four serotonin receptor genes, serotonin transporter gene and alcohol-related suicide. Psychiatr Danub 2010, 22:522-527. 
97. Arango V, Ernsberger P, Sved AF, Mann JJ: Quantitative autoradiography of alpha 1- and alpha 2-adrenergic receptors in the cerebral cortex of controls and suicide victims. Brain Res 1993, 630:271-282.

98. Meana JJ, Garcia-Sevilla JA: Increased alpha 2-adrenoceptor density in the frontal cortex of depressed suicide victims. J Neural Transm 1987, 70:377-381.

99. Gonzalez AM, Pascual J, Meana JJ, Barturen F, del Arco C, Pazos A, GarciaSevilla JA: Autoradiographic demonstration of increased alpha 2adrenoceptor agonist binding sites in the hippocampus and frontal cortex of depressed suicide victims. J Neurochem 1994, 63:256-265.

100. Ordway GA, Widdowson PS, Smith KS, Halaris A: Agonist binding to alpha 2- adrenoceptors is elevated in the locus coeruleus from victims of suicide. J Neurochem 1994, 63:617-624.

101. Ordway GA: Pathophysiology of the locus coeruleus in suicide. Ann N Y Acad Sci 1997, 836:233-252.

102. Gross-Isseroff R, Weizman A, Fieldust SJ, Israeli M, Biegon A: Unaltered alpha(2)- noradrenergic/imidazoline receptors in suicide victims: a postmortem brain autoradiographic analysis. Eur Neuropsychopharmacol 2000, 10:265-271.

103. Schambra UB, Mackensen GB, Stafford-Smith M, Haines DE, Schwinn DA: Neuron specific alpha-adrenergic receptor expression in human cerebellum: implications for emerging cerebellar roles in neurologic disease. Neuroscience 2005, 135:507-523.

104. Szot P, White SS, Greenup JL, Leverenz JB, Peskind ER, Raskind MA: Alpha1adrenoreceptor in human hippocampus: binding and receptor subtype mRNA expression. Brain Res Mol Brain Res 2005, 139:367-371.

105. De Paermentier F, Mauger JM, Lowther S, Crompton MR, Katona CL, Horton RW: Brain alpha-adrenoceptors in depressed suicides. Brain Res 1997, 757:60-68.

106. Meana JJ, Barturen F, Garcia-Sevilla JA: Alpha 2-adrenoceptors in the brain of suicide victims: increased receptor density associated with major depression. Biol Psychiatry 1992, 31:471-490.

107. Callado LF, Meana JJ, Grijalba B, Pazos A, Sastre M, Garcia-Sevilla JA: Selective increase of alpha2A-adrenoceptor agonist binding sites in brains of depressed suicide victims. J Neurochem 1998, 70:1114-1123.

108. Gonzalez-Maeso J, Rodriguez-Puertas R, Meana JJ, Garcia-Sevilla JA, Guimon $J$ : Neurotransmitter receptor-mediated activation of G-proteins in brains of suicide victims with mood disorders: selective supersensitivity of alpha(2A)- adrenoceptors. Mol Psychiatry 2002, 7:755-767.

109. Garcia-Sevilla JA, Escriba PV, Ozaita A, La Harpe R, Walzer C, Eytan A, Guimon J: Up-regulation of immunolabeled alpha2A-adrenoceptors, Gi coupling proteins, and regulatory receptor kinases in the prefrontal cortex of depressed suicides. J Neurochem 1999, 72:282-291.

110. Arango V, Underwood MD, Mann JJ: Alterations in monoamine receptors in the brain of suicide victims. J Clin Psychopharmacol 1992, 12:8S-12S.

111. Gurguis GN, Turkka J, Laruelle M, Kleinman J, Linnoila M: Coupling efficiency of brain beta-adrenergic receptors to $\mathrm{Gs}$ protein in suicide, alcoholism and control subjects. Psychopharmacology (Berl) 1999, 145:31-38.

112. Little KY, Ranc J, Gilmore J, Patel A, Clark TB: Lack of pineal beta-adrenergic receptor alterations in suicide victims with major depression. Psychoneuroendocrinology 1997, 22:53-62.

113. Sastre M, Guimon J, Garcia-Sevilla JA: Relationships between beta- and alpha2- adrenoceptors and $\mathrm{G}$ coupling proteins in the human brain: effects of age and suicide. Brain Res 2001, 898:242-255.

114. Sequeira A, Mamdani F, Lalovic A, Anguelova M, Lesage A, Seguin M, Chawky N, Desautels A, Turecki G: Alpha 2A adrenergic receptor gene and suicide. Psychiatry Res 2004, 125:87-93.

115. Martin-Guerrero I, Callado LF, Saitua K, Rivero G, Garcia-Orad A, Meana JJ: The N251K functional polymorphism in the alpha(2A)-adrenoceptor gene is not associated with depression: a study in suicide completers Psychopharmacology (Berl) 2006, 184:82-86.

116. Fukutake M, Hishimoto A, Nishiguchi N, Nushida H, Ueno Y, Shirakawa O, Maeda K: Association of alpha2A-adrenergic receptor gene polymorphism with susceptibility to suicide in Japanese females. Prog Neuropsychopharmacol Biol Psychiatry 2008, 32:1428-1433.

117. Molnar S, Mihanovic M, Grah M, Kezic S, Filakovic P, Degmecic D: Comparative study on gene tags of the neurotransmission system in schizophrenic and suicidal subjects. Coll Antropol 2010, 34:1427-1432.

118. Arango V, Underwood MD, Mann JJ: Fewer pigmented locus coeruleus neurons in suicide victims: preliminary results. Biol Psychiatry 1996, 39:112-120.
119. Nowak G, Szewczyk B, Sadlik K, Piekoszewski W, Trela F, Florek E, Pilc A: Reduced potency of zinc to interact with NMDA receptors in hippocampal tissue of suicide victims. Pol J Pharmacol 2003, 55:455-459.

120. Persson ML, Wasserman D, Geijer T, Jonsson EG, Terenius L: Tyrosine hydroxylase allelic distribution in suicide attempters. Psychiatry Res 1997 72:73-80.

121. De Luca V, Strauss J, Kennedy JL: Power based association analysis (PBAT) of serotonergic and noradrenergic polymorphisms in bipolar patients with suicidal behaviour. Prog Neuropsychopharmacol Biol Psychiatry 2008, 32:197-203.

122. Hattori H, Shirakawa O, Nishiguchi N, Nushida H, Ueno Y, Maeda K: No evidence of an association between tyrosine hydroxylase gene polymorphisms and suicide victims. Kobe J Med Sci 2006, 52:195-200.

123. Biegon A, Fieldust S: Reduced tyrosine hydroxylase immunoreactivity in locus coeruleus of suicide victims. Synapse 1992, 10:79-82.

124. Ettinger U, Kumari V, Collier DA, Powell J, Luzi S, Michel TM, Zedomi O, Williams SC: Catechol-O-methyltransferase (COMT) val158met genotype is associated with BOLD response as a function of task characteristic. Neuropsychopharmacology 2008, 33:3046-3057.

125. Sheldrick AJ, Krug A, Markov V, Leube D, Michel TM, Zerres K, Eggermann T, Kircher T: Effect of COMT val158met genotype on cognition and personality. Eur Psychiatry 2008, 23:385-389.

126. Ono H, Shirakawa O, Nushida H, Ueno Y, Maeda K: Association between catechol- O-methyltransferase functional polymorphism and male suicide completers. Neuropsychopharmacology 2004, 29:1374-1377.

127. Bowden C, Cheetham SC, Lowther S, Katona CL, Crompton MR, Horton RW: Reduced dopamine turnover in the basal ganglia of depressed suicides. Brain Res 1997, 769:135-140.

128. Allard P, Norlen M: Unchanged density of caudate nucleus dopamine uptake sites in depressed suicide victims. J Neural Transm 1997, 104:1353-1360.

129. Feldcamp LA, Souza RP, Romano-Silva M, Kennedy JL, Wong AH: Reduced prefrontal cortex DARPP-32 mRNA in completed suicide victims with schizophrenia. Schizophr Res 2008, 103:192-200.

130. Nowak G, Ordway GA, Paul IA: Alterations in the N-methyl-D-aspartate (NMDA) receptor complex in the frontal cortex of suicide victims. Brain Res 1995, 675:157-164.

131. Palmer AM, Burns MA, Arango V, Mann JJ: Similar effects of glycine, zinc and an oxidizing agent on [3H]dizocilpine binding to the N-methyl-Daspartate receptor in neocortical tissue from suicide victims and controls. J Neural Transm Gen Sect 1994, 96:1-8.

132. Holemans S, De Paermentier F, Horton RW, Crompton MR, Katona CL, Maloteaux JM: NMDA glutamatergic receptors, labelled with [3H]MK-801, in brain samples from drug-free depressed suicides. Brain Res 1993, 616:138-143.

133. Freed WJ, Dillon-Carter O, Kleinman JE: Properties of [3H]AMPA binding in postmortem human brain from psychotic subjects and controls: increases in caudate nucleus associated with suicide. Exp Neurol 1993, 121:48-56.

134. Noga JT, Hyde TM, Herman MM, Spurney CF, Bigelow LB, Weinberger DR, Kleinman JE: Glutamate receptors in the postmortem striatum of schizophrenic, suicide, and control brains. Synapse 1997, 27:168-176.

135. Kalkman HO: Circumstantial evidence for a role of glutamine-synthetase in suicide. Med Hypotheses 2011, 76:905-907

136. Marcus SR, Nadiger HA, Chandrakala MV, Rao TI, Sadasivudu B: Acute and short- term effects of lithium on glutamate metabolism in rat brain. Biochem Pharmacol 1986, 35:365-369.

137. Cheetham SC, Crompton MR, Katona CL, Parker SJ, Horton RW: Brain GABAA/benzodiazepine binding sites and glutamic acid decarboxylase activity in depressed suicide victims. Brain Res 1988, 460:114-123.

138. Vinod KY, Arango V, Xie S, Kassir SA, Mann JJ, Cooper TB, Hungund BL: Elevated levels of endocannabinoids and CB1 receptor-mediated G protein signaling in the prefrontal cortex of alcoholic suicide victims. Biol Psychiatry 2005, 57:480-486.

139. Hungund BL, Vinod KY, Kassir SA, Basavarajappa BS, Yalamanchili R, Cooper $\mathrm{TB}$, Mann JJ, Arango V: Upregulation of CB1 receptors and agoniststimulated [35S]GTPgammaS binding in the prefrontal cortex of depressed suicide victims. Mol Psychiatry 2004, 9:184-190.

140. Dwivedi Y, Conley RR, Roberts RC, Tamminga CA, Pandey GN: [(3)H]cAMP binding sites and protein kinase a activity in the prefrontal cortex of suicide victims. Am J Psychiatry 2002, 159:66-73. 
141. Dwivedi Y, Rizavi HS, Shukla PK, Lyons J, Faludi G, Palkovits M, Sarosi A, Conley RR, Roberts RC, Tamminga CA, Pandey GN: Protein kinase A in postmortem brain of depressed suicide victims: altered expression of specific regulatory and catalytic subunits. Biol Psychiatry 2004, 55:234-243

142. Dwivedi Y, Rao JS, Rizavi HS, Kotowski J, Conley RR, Roberts RC, Tamminga CA Pandey GN: Abnormal expression and functional characteristics of cyclic adenosine monophosphate response element binding protein in postmortem brain of suicide subjects. Arch Gen Psychiatry 2003, 60:273-282.

143. Pandey GN, Dwivedi Y, Ren X, Rizavi HS, Mondal AC, Shukla PK, Conley RR: Brain region specific alterations in the protein and $m R N A$ levels of protein kinase A subunits in the post-mortem brain of teenage suicide victims. Neuropsychopharmacology 2005, 30:1548-1556.

144. Dwivedi Y, Mondal AC, Rizavi HS, Faludi G, Palkovits M, Sarosi A, Conley RR, Pandey GN: Differential and brain region-specific regulation of Rap-1 and Epac in depressed suicide victims. Arch Gen Psychiatry 2006, 63:639-648.

145. Valdizan EM, Gutierrez O, Pazos A: Adenylate cyclase activity in postmortem brain of suicide subjects: reduced response to betaadrenergic stimulation. Biol Psychiatry 2003, 54:1457-1464.

146. Nishizuka Y: Studies and prospectives of protein kinase $C$ in signal transduction. Nihon Ketsueki Gakkai Zasshi 1988, 51:1321-1326.

147. Akimoto K, Mizuno K, Osada S, Hirai S, Tanuma S, Suzuki K, Ohno S: A new member of the third class in the protein kinase C family, PKC lambda, expressed dominantly in an undifferentiated mouse embryonal carcinoma cell line and also in many tissues and cells. J Biol Chem 1994, 269:12677-12683.

148. Ono Y, Fujii T, Ogita K, Kikkawa U, Igarashi K, Nishizuka Y: Protein kinase C zeta subspecies from rat brain: its structure, expression, and properties. Proc Natl Acad Sci U S A 1989, 86:3099-3103.

149. Tanaka C, Nishizuka Y: The protein kinase $C$ family for neuronal signaling Annu Rev Neurosci 1994, 17:551-567.

150. Pandey GN, Dwivedi Y, Rizavi HS, Ren X, Conley RR: Decreased catalytic activity and expression of protein kinase $C$ isozymes in teenage suicide victims: a postmortem brain study. Arch Gen Psychiatry 2004, 61:685-693.

151. Choi K, Le T, Xing G, Johnson LR, Ursano RJ: Analysis of kinase gene expression in the frontal cortex of suicide victims: implications of fear and stress. Front Behav Neurosci 2011, 5:46.

152. Pandey GN, Dwivedi $Y$, SridharaRao J, Ren $X$, Janicak PG, Sharma R: Protein kinase $C$ and phospholipase $C$ activity and expression of their specific isozymes is decreased and expression of MARCKS is increased in platelets of bipolar but not in unipolar patients. Neuropsychopharmacology 2002, 26:216-228.

153. Pandey GN, Dwivedi Y, Ren X, Rizavi HS, Roberts RC, Conley RR, Tamminga C: Altered expression and phosphorylation of myristoylated alanine-rich $C$ kinase substrate (MARCKS) in postmortem brain of suicide victims with or without depression. J Psychiatr Res 2003, 37:421-432

154. Odagaki Y, Garcia-Sevilla JA, Huguelet P, La Harpe R, Koyama T, Guimon J: Cyclic AMP-mediated signaling components are upregulated in the prefrontal cortex of depressed suicide victims. Brain Res 2001, 898:224-231.

155. Young LT, Bezchlibnyk YB, Chen B, Wang JF, MacQueen GM: Amygdala cyclic adenosine monophosphate response element binding protein phosphorylation in patients with mood disorders: effects of diagnosis, suicide, and drug treatment. Biol Psychiatry 2004, 55:570-577.

156. Pandey GN, Dwivedi Y, Ren X, Rizavi HS, Roberts RC, Conley RR: Cyclic AMP response element-binding protein in post-mortem brain of teenage suicide victims: specific decrease in the prefrontal cortex but not the hippocampus. Int J Neuropsychopharmacol 2007, 10:621-629.

157. Bonaccorso S, Marino V, Biondi M, Grimaldi F, Ippoliti F, Maes M: Depression induced by treatment with interferon-alpha in patients affected by hepatitis C virus. J Affect Disord 2002, 72:237-241.

158. Bonaccorso S, Puzella A, Marino V, Pasquini M, Biondi M, Artini M, Almerighi C, Levrero M, Egyed B, Bosmans E, Meltzer HY, Maes M: Immunotherapy with interferon- alpha in patients affected by chronic hepatitis $C$ induces an intercorrelated stimulation of the cytokine network and an increase in depressive and anxiety symptoms. Psychiatry Res 2001, 105:45-55.

159. Berk M, Wadee AA, Kuschke RH, O'Neill-Kerr A: Acute phase proteins in major depression. J Psychosom Res 1997, 43:529-534.

160. Kubera M, Kenis G, Bosmans E, Zieba A, Dudek D, Nowak G, Maes M: Plasma levels of interleukin-6, interleukin-10, and interleukin-1 receptor antagonist in depression: comparison between the acute state and after remission. Pol J Pharmacol 2000, 52:237-241.
161. Maes M: Evidence for an immune response in major depression: a review and hypothesis. Prog Neuropsychopharmacol Biol Psychiatry 1995, 19:11-38.

162. Carpenter LL, Gawuga CE, Tyrka AR, Lee JK, Anderson GM, Price LH: Association between plasma IL-6 response to acute stress and early-life adversity in healthy adults. Neuropsychopharmacology 2010, 35:2617-2623.

163. Minami M, Kuraishi Y, Yamaguchi T, Nakai S, Hirai Y, Satoh M: Immobilization stress induces interleukin-1 beta mRNA in the rat hypothalamus. Neurosci Lett 1991, 123:254-256.

164. Lindqvist D, Janelidze S, Hagell P, Erhardt S, Samuelsson M, Minthon L, Hansson O, Bjorkqvist M, Traskman-Bendz L, Brundin L: Interleukin-6 is elevated in the cerebrospinal fluid of suicide attempters and related to symptom severity. Biol Psychiatry 2009, 66:287-292.

165. Steiner J, Bielau H, Brisch R, Danos P, Ullrich O, Mawrin C, Bernstein HG, Bogerts $B$ : Immunological aspects in the neurobiology of suicide: elevated microglial density in schizophrenia and depression is associated with suicide. J Psychiatr Res 2008, 42:151-157.

166. Tonelli LH, Stiller J, Rujescu D, Giegling I, Schneider B, Maurer K, Schnabel A, Moller HJ, Chen HH, Postolache TT: Elevated cytokine expression in the orbitofrontal cortex of victims of suicide. Acta Psychiatr Scand 2008, 117:198-206.

167. Pandey GN, Rizavi HS, Ren X, Fareed J, Hoppensteadt DA, Roberts RC, Conley RR, Dwivedi Y: Proinflammatory cytokines in the prefrontal cortex of teenage suicide victims. J Psychiatr Res 2012, 46:57-63.

168. Huang EJ, Reichardt LF: Neurotrophins: roles in neuronal development and function. Annu Rev Neurosci 2001, 24:677-736.

169. Nibuya M, Nestler EJ, Duman RS: Chronic antidepressant administration increases the expression of CAMP response element binding protein (CREB) in rat hippocampus. J Neurosci 1996, 16:2365-2372.

170. Durany N, Michel T, Kurt J, Cruz-Sanchez FF, Cervas-Navarro J, Riederer P. Brain- derived neurotrophic factor and neurotrophin-3 levels in Alzheimer's disease brains. Int J Dev Neurosci 2000, 18:807-813.

171. Durany N, Michel T, Zochling R, Boissl KW, Cruz-Sanchez FF, Riederer P, Thome J: Brain-derived neurotrophic factor and neurotrophin 3 in schizophrenic psychoses. Schizophr Res 2001, 52:79-86.

172. Dwivedi Y, Rizavi HS, Conley RR, Roberts RC, Tamminga CA, Pandey GN: Altered gene expression of brain-derived neurotrophic factor and receptor tyrosine kinase $B$ in postmortem brain of suicide subjects. Arch Gen Psychiatry 2003, 60:804-815.

173. Karege F, Vaudan G, Schwald M, Perroud N, La Harpe R: Neurotrophin levels in postmortem brains of suicide victims and the effects of antemortem diagnosis and psychotropic drugs. Brain Res Mol Brain Res 2005, 136:29-37.

174. Sarchiapone M, Carli V, Roy A, lacoviello L, Cuomo C, Latella MC, di Giannantonio M, Janiri L, de Gaetano M, Janal MN: Association of polymorphism (Val66Met) of brain-derived neurotrophic factor with suicide attempts in depressed patients. Neuropsychobiology 2008, 57:139-145.

175. Zai CC, Manchia M, De Luca V, Tiwari AK, Chowdhury NI, Zai GC, Tong RP, Yilmaz Z, Shaikh SA, Strauss J, Kennedy JL: The brain-derived neurotrophic factor gene in suicidal behaviour: a meta-analysis. Int $J$ Neuropsychopharmacol 2012, 15:1037-1042.

176. de Luca V, Souza RP, Zai CC, Panariello F, Javaid N, Strauss J, Kennedy JL, Tallerico T, Wong AH: Parent of origin effect and differential allelic expression of BDNF Val66Met in suicidal behaviour. World J Biol Psychiatry 2011, 12:42-47.

177. Ernst C, Deleva V, Deng X, Sequeira A, Pomarenski A, Klempan T, Ernst N, Quirion R, Gratton A, Szyf M, Turecki G: Alternative splicing, methylation state, and expression profile of tropomyosin-related kinase $B$ in the frontal cortex of suicide completers. Arch Gen Psychiatry 2009, 66:22-32.

178. Takebayashi M, Hisaoka K, Nishida A, Tsuchioka M, Miyoshi I, Kozuru T, Hikasa S, Okamoto Y, Shinno H, Morinobu S, Yamawaki S: Decreased levels of whole blood glial cell line-derived neurotrophic factor (GDNF) in remitted patients with mood disorders. Int J Neuropsychopharmacol 2006, 9:607-612

179. Hisaoka K, Maeda N, Tsuchioka M, Takebayashi M: Antidepressants induce acute CREB phosphorylation and CRE-mediated gene expression in glial cells: a possible contribution to GDNF production. Brain Res 2008, 1196:53-58

180. Hisaoka K, Nishida A, Koda T, Miyata M, Zensho H, Morinobu S, Ohta M, Yamawaki S: Antidepressant drug treatments induce glial cell linederived neurotrophic factor (GDNF) synthesis and release in rat C6 glioblastoma cells. J Neurochem 2001, 79:25-34. 
181. Hisaoka K, Tsuchioka M, Yano R, Maeda N, Kajitani N, Morioka N, Nakata Y, Takebayashi M: Tricyclic antidepressant amitriptyline activates fibroblast growth factor receptor signaling in glial cells: involvement in glial cell linederived neurotrophic factor production. J Biol Chem 2011, 286:21118-21128.

182. Otsuki K, Uchida S, Watanuki T, Wakabayashi Y, Fujimoto M, Matsubara T, Funato $\mathrm{H}$, Watanabe $\mathrm{Y}$ : Altered expression of neurotrophic factors in patients with major depression. J Psychiatr Res 2008, 42:1145-1153.

183. Gilad VH, Rabey JM, Kimiagar Y, Gilad GM: The polyamine stress response: tissue-, endocrine-, and developmental-dependent regulation. Biochem Pharmacol 2001, 61:207-213.

184. Igarashi K, Kashiwagi K: Modulation of cellular function by polyamines. Int J Biochem Cell Biol 2010, 42:39-51.

185. Seiler N, Atanassov CL: The natural polyamines and the immune system. Prog Drug Res 1994, 43:87-141.

186. Fiori LM, Turecki G: Implication of the polyamine system in mental disorders. J Psychiatry Neurosci 2008, 33:102-110.

187. Sequeira A, Gwadry FG, Ffrench-Mullen JM, Canetti L, Gingras Y, Casero RA Jr, Rouleau G, Benkelfat C, Turecki G: Implication of SSAT by gene expression and genetic variation in suicide and major depression. Arch Gen Psychiatry 2006, 63:35-48.

188. Fiori LM, Mechawar N, Turecki G: Identification and characterization of spermidine/spermine $\mathrm{N} 1$-acetyltransferase promoter variants in suicide completers. Biol Psychiatry 2009, 66:460-467.

189. Klempan TA, Rujescu D, Merette C, Himmelman C, Sequeira A, Canetti L, Fiori LM, Schneider B, Bureau A, Turecki G: Profiling brain expression of the spermidine/spermine N1-acetyltransferase 1 (SAT1) gene in suicide. Am J Med Genet B Neuropsychiatr Genet 2009, 150B:934-943.

190. Guipponi M, Deutsch S, Kohler K, Perroud N, Le Gal F, Vessaz M, Laforge T, Petit B, Jollant F, Guillaume S, Baud P, Courtet P, La Harpe R, Malafosse A: Genetic and epigenetic analysis of SSAT gene dysregulation in suicidal behavior. Am J Med Genet B Neuropsychiatr Genet 2009, 150B:799-807.

191. Fiori LM, Turecki G: Epigenetic regulation of spermidine/spermine N1acetyltransferase (SAT1) in suicide. J Psychiatr Res 2011, 45:1229-1235.

192. Fiori LM, Bureau A, Labbe A, Croteau J, Noel S, Merette C, Turecki G: Global gene expression profiling of the polyamine system in suicide completers. Int J Neuropsychopharmacol 2011, 14:595-605.

193. Fiori LM, Wanner B, Jomphe V, Croteau J, Vitaro F, Tremblay RE, Bureau A, Turecki G: Association of polyaminergic loci with anxiety, mood disorders, and attempted suicide. PLoS One 2010, 5:e15146.

194. Chen GG, Fiori LM, Moquin L, Gratton A, Mamer O, Mechawar N, Turecki G Evidence of altered polyamine concentrations in cerebral cortex of suicide completers. Neuropsychopharmacology 2010, 35:1477-1484.

195. Chen GG, Turecki G, Mamer OA: A quantitative GC-MS method for three major polyamines in postmortem brain cortex. J Mass Spectrom 2009, 44:1203-1210.

196. Carroll BJ: The dexamethasone suppression test for melancholia. $\mathrm{Br} \mathrm{J}$ Psychiatry 1982, 140:292-304.

197. Holsboer F: The corticosteroid receptor hypothesis of depression. Neuropsychopharmacology 2000, 23:477-501.

198. Nemeroff CB: The corticotropin-releasing factor (CRF) hypothesis of depression: new findings and new directions. Mol Psychiatry 1996, 1:336-342

199. Yerevanian Bl, Feusner JD, Koek RJ, Mintz J: The dexamethasone suppression test as a predictor of suicidal behavior in unipolar depression. J Affect Disord 2004, 83:103-108.

200. Coryell W, Schlesser M: The dexamethasone suppression test and suicide prediction. Am J Psychiatry 2001, 158:748-753.

201. Banki CM, Arato M, Papp Z, Kurcz M: Biochemical markers in suicidal patients. Investigations with cerebrospinal fluid amine metabolites and neuroendocrine tests. J Affect Disord 1984, 6:341-350.

202. Targum SD, Rosen L, Capodanno AE: The dexamethasone suppression test in suicidal patients with unipolar depression. Am J Psychiatry 1983, 140:877-879.

203. Black DW, Monahan PO, Winokur G: The relationship between DST results and suicidal behavior. Ann Clin Psychiatry 2002, 14:83-88.

204. Brown RP, Mason B, Stoll P, Brizer D, Kocsis J, Stokes PE, Mann JJ: Adrenocortical function and suicidal behavior in depressive disorders. Psychiatry Res 1986, 17:317-323.

205. Raadsheer FC, Hoogendijk WJ, Stam FC, Tilders FJ, Swaab DF: Increased numbers of corticotropin-releasing hormone expressing neurons in the hypothalamic paraventricular nucleus of depressed patients.

Neuroendocrinology 1994, 60:436-444
206. Merali Z, Du L, Hrdina P, Palkovits M, Faludi G, Poulter MO, Anisman H: Dysregulation in the suicide brain: mRNA expression of corticotropinreleasing hormone receptors and $G A B A(A)$ receptor subunits in frontal cortical brain region. J Neurosci 2004, 24:1478-1485.

207. Merali Z, Kent P, Du L, Hrdina P, Palkovits M, Faludi G, Poulter MO, Bedard T, Anisman $\mathrm{H}$ : Corticotropin-releasing hormone, arginine vasopressin, gastrin- releasing peptide, and neuromedin B alterations in stressrelevant brain regions of suicides and control subjects. Biol Psychiatry 2006, 59:594-602.

208. Austin MC, Janosky JE, Murphy HA: Increased corticotropin-releasing hormone immunoreactivity in monoamine-containing pontine nuclei of depressed suicide men. Mol Psychiatry 2003, 8:324-332.

209. Nemeroff CB, Owens MJ, Bissette G, Andorn AC, Stanley M: Reduced corticotropin releasing factor binding sites in the frontal cortex of suicide victims. Arch Gen Psychiatry 1988, 45:577-579.

210. Hiroi N, Wong ML, Licinio J, Park C, Young M, Gold PW, Chrousos GP, Bornstein SR: Expression of corticotropin releasing hormone receptors type I and type II mRNA in suicide victims and controls. Mol Psychiatry 2001, 6:540-546.

211. Pariante CM: Glucocorticoid receptor function in vitro in patients with major depression. Stress 2004, 7:209-219.

212. Perlman WR, Webster MJ, Kleinman JE, Weickert CS: Reduced glucocorticoid and estrogen receptor alpha messenger ribonucleic acid levels in the amygdala of patients with major mental illness. Biol Psychiatry 2004, 56:844-852

213. Webster MJ, Knable MB, O'Grady J, Orthmann J, Weickert CS: Regional specificity of brain glucocorticoid receptor mRNA alterations in subjects with schizophrenia and mood disorders. Mol Psychiatry 2002, 7:985-994.

214. Lopez JF, Palkovits M, Arato M, Mansour A, Akil H, Watson SJ: Localization and quantification of pro-opiomelanocortin mRNA and glucocorticoid receptor mRNA in pituitaries of suicide victims. Neuroendocrinology 1992, 56:491-501.

215. McGowan PO, Sasaki A, D'Alessio AC, Dymov S, Labonte B, Szyf M, Turecki G, Meaney MJ: Epigenetic regulation of the glucocorticoid receptor in human brain associates with childhood abuse. Nat Neurosci 2009, 12:342-348.

216. Supriyanto I, Sasada T, Fukutake M, Asano M, Ueno Y, Nagasaki Y, Shirakawa O, Hishimoto A: Association of FKBP5 gene haplotypes with completed suicide in the Japanese population. Prog Neuropsychopharmacol Biol Psychiatry 2011, 35:252-256.

217. Fountoulakis M, Hardmeier R, Hoger H, Lubec G: Postmortem changes in the level of brain proteins. Exp Neurol 2001, 167:86-94.

218. Kim CD, Seguin M, Therrien N, Riopel G, Chawky N, Lesage AD, Turecki G: Familial aggregation of suicidal behavior: a family study of male suicide completers from the general population. Am J Psychiatry 2005, 162:1017-1019.

doi:10.1186/2049-9256-1-2

Cite this article as: Furczyk et al:: The neurobiology of suicide - A Review of post-mortem studies. Journal of Molecular Psychiatry 2013 1:2.

\section{Submit your next manuscript to BioMed Central and take full advantage of:}

- Convenient online submission

- Thorough peer review

- No space constraints or color figure charges

- Immediate publication on acceptance

- Inclusion in PubMed, CAS, Scopus and Google Scholar

- Research which is freely available for redistribution 